\title{
Structural analysis of the Planchón-Peteroa Volcanic Complex: Insights for the geothermal system
}

\author{
Nicolás Vigide ${ }^{\mathrm{a}, *}$, Daniel Yagupsky ${ }^{\mathrm{a}}$, Hernan Barcelona ${ }^{\mathrm{a}}$, Mariano Agusto ${ }^{\mathrm{a}}$, Alberto Caselli ${ }^{\mathrm{b}, \mathrm{c}}$ \\ ${ }^{a}$ CONICET- IDEAN, Instituto de Estudios Andinos "Don Pablo Groeber, Universidad de Buenos Aires, Intendente Güiraldes 2160, Buenos Aires, C1428EHA, Argentina \\ ${ }^{\mathrm{b}}$ Universidad Nacional de Río Negro, Instituto de Investigación en Paleobiología y Geología, Río Negro, Argentina

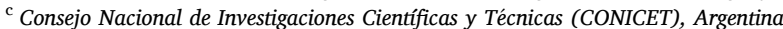

\section{A R T I C L E I N F O}

\section{Keywords:}

Paleostress tensor inversion

Slip-dilation tendency analysis

Andean volcanic arc

Fluid migration

\begin{abstract}
A B S T R A C T
The Planchón-Peteroa Volcanic Complex (PPVC) is located in the Transitional Southern Volcanic Zone of the Andean Ridge. Structural control of the main NNE-striking El Fierro fault system (EFFS) over the volcanic activity has been commonly assumed, although a paucity of evidence remains. The aim of this paper is to explore the relationship between the local stress field, the superficial structural setting and the geothermal fluid flow paths related to the volcanic complex. To conduct the structural analysis, this work combines remote sensing determination of lineaments, recognition of fracture patterns, with the inversion of kinematic indicators on outcrop scale faults, to finally evaluate the role of the local stress field over the $2 \mathrm{D}$ slip and dilation tendencies of the recognized structures. Mesoscale morphostructural lineaments present three main directions: $\sim \mathrm{E}-\mathrm{W}, \sim \mathrm{NE}-\mathrm{SW}$, and $\sim$ NW-SE. Major lineaments develop inflections, giving rise to left bends between the NW-SE to E-W along the strike, compartmentalized by $\sim$ NNE trending lineaments. Strike-slip fault solutions with an ENE-WSW to NE-SW oriented shortening axis were obtained from fault-slip data analysis. The inversion of fault kinematic indicators constrains a Quaternary to recent strike-slip regime, with a $\sim$ ENE-WSW trending $\sigma_{1}$, and a subvertical $\sigma_{2}$. Under the defined local stress field, $\sim$ NE-SW and $\sim$ WNW-ESE oriented structures have high slip tendency, while those spanning from NE-SW to E-W are prone to dilate. Our analysis suggests that these transverse structures exert firstorder controls on the location of Vergara Pass Hill, and Peñón River and Azufre River Valleys hydrothermal manifestations. It seems that intersection zones with submeridian structures, as EFFS, increase structural damage and facilitate hot fluid migration. Circulation would profit the most from $\sim$ ENE-WSW and $\sim$ NW-SE striking outcrop-scale faults and fractures associated with the damage zones.
\end{abstract}

\section{Introduction}

The determination of the stress field acting on a volcanic environment is important to define and predict the dynamic behaviour of local structures, which in turn control magmatic paths. Arrangements of structural elements (as faults and joints) and their spatial distribution constrain pathways for the migration, ascent, and emplacement of fluids in hydrothermal systems. Therefore, they have important implications for mineralization (e.g., Rowland and Sibson, 2004; Zhang et al., 2008; Bons et al., 2012), geothermal exploration, and assessment of volcanic hazards (e.g., Arnorsson, 1995; Rowland and Sibson, 2004; Caliro et al., 2005; Fridriksson et al., 2006; Hutchison et al., 2015).

The Planchón-Peteroa Volcanic Complex $\left(35.24^{\circ} \mathrm{S}, 7^{\circ} .57^{\circ} \mathrm{W}\right.$; hereafter PPVC) belongs to the Transitional Southern Volcanic Zone (TSVZ; Stern et al., 1984; Hildred and Moorbath, 1988) at the border between Argentina and Chile (Fig. 1); it is associated with the subduction of the Nazca plate beneath the South American plate (Barazangi and Isacks, 1976; Cande and Leslie, 1986, 1987). This volcanic complex is characterized by an N-S elongated multi-episodic building, with a crater caldera of $5 \mathrm{~km}$ diameter, where four minor crater lakes and intense fumarolic activity coexist (Benavente, 2015). Additionally, geothermal manifestations appear in the eastern side of the PPVC (Benavente, 2015; Aguilera et al., 2016; Tassi et al., 2016). The activity of Peteroa volcano has been relatively persistent since 2010, with frequent phreatomagmatic eruptions categorized by a volcanic explosivity index (VEI) $\leq$ 2 (Haller and Risso, 2011). However, the local structural setting of the

\footnotetext{
* Corresponding author. Facultad de Ciencias Exactas y Naturales, Universidad de Buenos Aires, Intendente Güiraldes 2160 Ciudad Universitaria - Pabellón, IIC1428EGA-CABA, Argentina.

E-mail address: ncvigide@gl.fcen.uba.ar (N. Vigide).
} 
PPVC and its role in fluid circulation has not been carefully examined. Surveys such as that conducted by Naranjo et al. (1999), Hevia-Cruz (2014), and Tapia et al. (2015) have defined the first-order structural elements. Recent studies get detail on the volcanic-hydrothermal interaction in the Tatara-San-Pedro-Pellado Volcanic Complex (Sielfeld et al., 2019) and in the Tinguiririca volcanic-hydrothermal system
(Giambiagi et al., 2019), to the south and north of the study area, respectively.

In this work, we analyze the relationship between the local stress, the structural setting and the geothermal fluid flow paths related to the PPVC. To carry out this analysis, we combine remote sensing determination of lineaments, with the inversion of kinematic indicators on

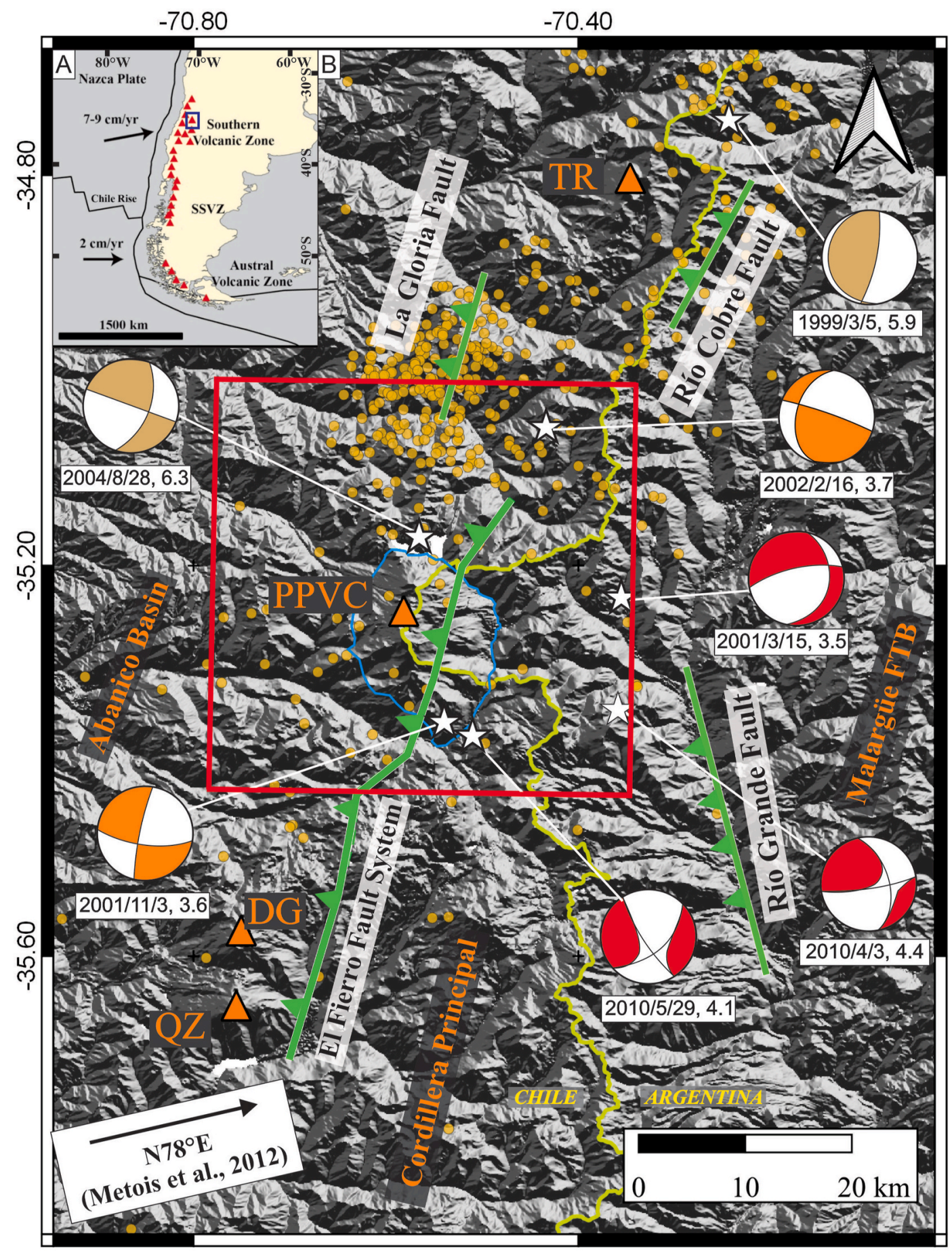

Fig. 1. A) Tectonic framework of the Andean margin. The arrows indicate the absolute plate motion; red triangles indicate the volcanic arc; the blue rectangle shows the location of Fig. 1B. B) Digital elevation model (DEM); regional fault systems are denoted in bold green line (taken from Spagnotto et al., 2015). The study area is indicated by the red box; blue line indicates the PPVC contour. Focal mechanisms (lower hemisphere compressional quadrants) are shown, obtained from Spagnotto et al. (2015) (red); Global Centroid-Moment Tensor (GCMT) database (light brown); Villegas et al. (2016) (orange); epicenters are shown with white stars, date and magnitude in squares. Light-brown dots are crustal seismic events ( $<15 \mathrm{~km}$ depth) from 1980 to 2020 USGS earthquake dataset. Black arrow represents a shortening parallel to the plate convergence vector from the kinematic modeling of GPS data (Métois et al., 2012). Orange triangles are principal volcano edifices. PPVC: Planchón-Peteroa Volcanic Complex. TR: Tingiririca volcano. DG: Descabezado Grande volcano. QZ: Quizapu volcano. (For interpretation of the references to color in this figure legend, the reader is referred to the Web version of this article.) 
outcrop scale faults and determination of fracture patterns, to finally evaluate the role of the local stress field over the slip and dilation tendencies of the recognized structures. From these observations, we explore the control exerted by different families of structures over the geothermal fluid migration.

\section{Planchón-Peteroa Volcanic Complex geological settings}

\subsection{Tectonic setting}

Through late Triassic to early Jurassic, extension in the Neuquén basin was characterized by the development of several isolated depocenters with master faults striking NW to NNE (Manceda and Figueroa, 1995; Vergani et al., 1995; Giambiagi et al., 2009; Mescua et al., 2013). Triassic-Jurassic depocenters, located north of $35.5^{\circ} \mathrm{S}$, were controlled by the NNE trending Río del Cobre master fault (Mescua et al., 2013) while to the south of $35.5^{\circ} \mathrm{S}$, depocenters were controlled by the N-NW trending Río Grande master fault (Manceda and Figueroa, 1995). The Abanico extensional basin was formed with $\mathrm{N}$ to NNE orientation immediately to the west of the Neuquén basin (Godoy et al., 1999; Charrier et al., 2002).

During the ca. 75-37 Ma period, an arc platform without obvious structural control is established for the $35^{\circ} \mathrm{S}$ latitude (Mosolf et al., 2019). From ca. 37 to $11 \mathrm{Ma}$, these authors propose an intra-arc dextral transpressive regime, based on well-dated growth-strata recognized on the upper levels of the Abanico Formation, in association with dextral-reverse faulting. This regime would be the response to trench-parallel strain related to oblique plate convergence (Mosolf et al., 2019; Piquer et al., 2019).

Through lower to middle Miocene, the eastern border normal faults of the Abanico basin were inverted, putting in tectonic contact the Cenozoic stratified volcanic units with Mesozoic deposits (Parada, 2008; Mescua et al., 2013; Hevia-Cruz, 2014; Tapia et al., 2015; Mosolf et al., 2019). The advance of the deformation to the east gave rise to the development of the Malargüe fold and thrust belt (Kozlowski et al., 1993). From late Miocene to present, a continuous contractional deformation dominates the area, controled by $\sim$ N-S and $\sim$ NE-SW structures (Farías et al., 2011; Tapia et al., 2015), and possibly accompanied by minor strike-slip faulting (Mosolf et al., 2019).

Finite deformation estimations based on a kinematic modeling of GPS data indicate shortening parallel to the plate convergence vector $\left(\sim \mathrm{N}^{\circ}{ }^{\circ} \mathrm{E}\right)$ for the Southern Central Andes (Métois et al., 2012). Spagnotto et al. (2015) proposed a strike-slip regime as the most favorable tectonic setting for the $35^{\circ}$ to $36^{\circ} \mathrm{S}$ segment, which could transitorily change to a right lateral/normal regime when more significant earthquakes occur; such as it was suggested for the 2004 and 2012 earthquakes (Farías, 2007; Comte et al., 2008).

The principal structures of the study area are named El Fierro fault system (hereafter EFFS; Fig. 1). It is important to note that El Fierro fault is a single NNE-SSW reverse fault defined by Davidson and Vicente (1973) in the Río Tinguiririca valley. However, the EFFS is represented as the continuation to the south of the fault system at the $35^{\circ} \mathrm{S}$ (Farías et al., 2010; Benavente, 2015), which is also interpreted as a part of the Abanico basin eastern margin (Farías et al., 2010). This fault system is formed by NNE-SSW striking, reverse faults, with variable dips to the west that increases from north to south (González-Contreras, 2008; Benavente, 2015; Mosolf et al., 2019).

\subsection{Stratigraphic framework}

The older rocks around the PPVC are the Mesozoic sequences represented by limestones, gypsum, sandstones and volcaniclastic deposits of the Lotena and Mendoza Groups in Argentina, correlated with Rio Damas and Baños del Flaco Formations in Chile (Naranjo et al., 1999; González-Contreras, 2008; Piquer et al., 2010; Tapia et al., 2015; Duran et al., 2016), outcropping in the eastern sector of the study area (Fig. 2).
During late Cretaceous to Eocene, intra-arc volcanic and volcaniclastic deposits formed the lower Abanico Formation upon a broad arc platform (Charrier et al., 1994, 1996; Godoy et al., 1999; Jordan et al., 2001; Mosolf et al., 2019). These rocks surround the northern and western sectors next to the PPVC (Fig. 2). Since Eocene to Miocene, the continued volcanism produced the upper Abanico Formation rocks (Mosolf et al., 2019), while some andesitic intrusive bodies and associated volcaniclastic deposits of Huincan Formation affected the area (Nullo et al., 2002).

From middle to late Pleistocene, the PPVC started to grow by the establishment of the Azufre volcano. It is located in the southern sector of the complex (Fig. 2), formed by $69 \mathrm{~km}^{3}$ of basaltic-andesitic to dacitic lavas and pyroclastic flows and lahar deposits (Tormey, 1989; Naranjo and Haller, 2002; Benavente, 2015).

The second phase of the complex growth corresponds to the Planchón volcano. The volcanic edifice is located $6 \mathrm{~km}$ north of the Azufre volcano (Fig. 2). Its activity occurred during the late Pleistocene (ca. 14 - $7 \mathrm{Ka}$ ). This volcanism is characterized by basaltic flows, basaltic andesites, and a debris avalanche produced by the collapse of its western flank. A new building grew up inside the top of the amphitheater product of the avalanche (northern crater in Fig. 2; Tormey, 1989; Haller et al., 1994; Tormey et al., 1995; Benavente, 2015).

Finally, the Peteroa volcanic edifice grew between the Azufre and Planchón volcanoes, about 7 ka ago (Tormey et al., 1995). This is the newest and smaller volcanic edifice $\left(<1 \mathrm{~km}^{3}\right)$ and is constituted by basalt-andesitic to andesitic lava flows and basalt-andesitic to dacitic pyroclastic deposits (Tormey, 1989; Naranjo et al., 1999; Haller and Risso, 2011; Benavente, 2015). According to Tormey et al. (1995), the volcanic complex deposits follow an evolution trend from a dominated basalts and subordinate dacites tholeiitic system (Azufre and Planchón volcanoes) generated at a relatively moderate pressure, to a dominant andesites calc-alkaline system (Peteroa volcano) formed by mixing magmas into the shallow crust.

\subsection{Geothermal system}

The volcanic complex thermal fluids are the result of the interaction between deep-origin gases and meteoric water, such as pluvial and snow precipitation, and summit glacier melts (Benavente, 2015; Aguilera et al., 2016; Tassi et al., 2016). Moreover, thermal springs, fumaroles, gas diffuse emissions, mud pools, bubbling pools, and cold springs appear at the eastern side of the complex (Fig. 2; Benavente, 2015; Aguilera et al., 2016; Tassi et al., 2016). Remarkably intense manifestations develop at the Azufre river valley.

Tassi et al. (2016) pointed out that two deep sources connected by a regional N-S structure feed the hydrothermal system. Geochemical data of the crater fumaroles indicate the presence of a magmatic source released fluids. These fumaroles are dominated by steam (Aguilera et al., 2016; Tassi et al., 2016). Fumarole outlet temperatures are close to $90{ }^{\circ} \mathrm{C}$, which is coincident with the boiling temperature at the Peteroa crater height (3400 $\mathrm{m}$ a.s.l.). This suggests the presence of a shallow aquifer, which is reloaded with the steam condensation (Tassi et al., 2016). Furthermore, geochemistry of hydrothermal manifestation on valleys of the eastern flank denotes a typical composition for low temperature peripherical discharges, with a low magmatic contribution (Benavente, 2015; Tassi et al., 2016).

\section{Methodology}

Different methodologies applied at different scales have been combined in order to understand the structural setting of the area of interest. First, a compilation of structures was performed based on published maps (Naranjo et al., 1999; Hevia-Cruz, 2014; Tapia et al., 2015), and complemented with the identification of first-order lineaments on satellite images. To identify morphostructures and structural lineaments of the intermediate scale of 1:25,000, a semi-automatic lineament 


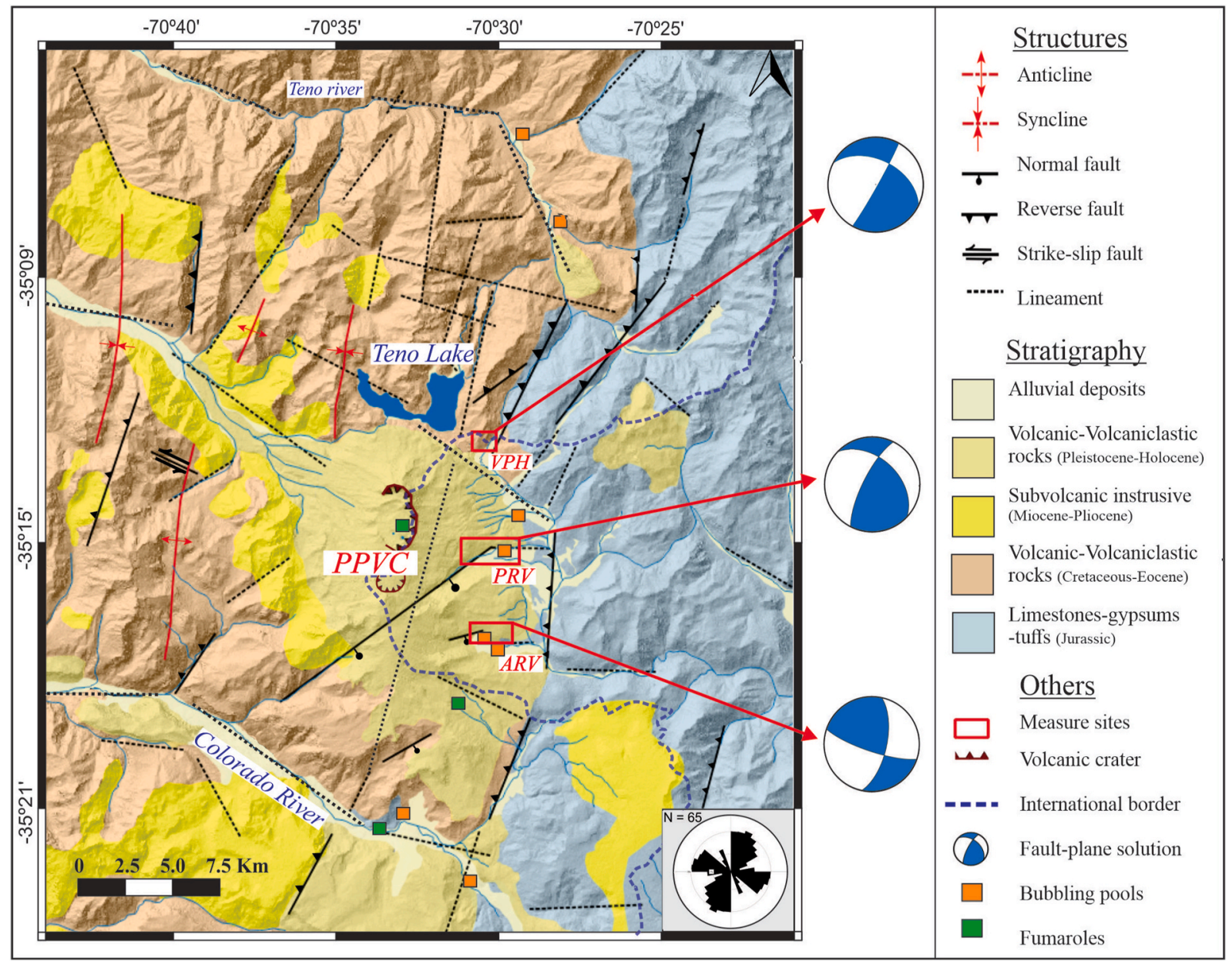

Fig. 2. Geological map of the area. Measure sites VPH: Vergara Pass Hill; PRV: Peñón River Valley; ARV: Azufre river valley. Fault plane solutions obtained by faultslip data in this work: blue quadrants indicate shortening direction; white quadrants are extensional direction. Mapped structures are compiled from Naranjo et al. (1999), Hevia-Cruz (2014), and Tapia et al. (2015). Inset shows a rose diagram of the mapped structures. Location of fumaroles and bubbling pools are taken from Benavente (2015), Aguilera et al. (2016) and Tassi et al. (2016). (For interpretation of the references to color in this figure legend, the reader is referred to the Web version of this article.)

identification based on digital elevation models has been applied (Wise et al., 1985; Dixon et al., 1998; Giordano et al., 2013). Second, a detailed structural field survey in different areas along the eastern flank of the PPVC has been performed. This survey includes the determination of kinematic indicators at outcrop-scale faults, as well as measurements of fracture populations. By the inversion of the obtained kinematic indicators, the local-associated reduced stress tensor was calculated in each measuring site. Finally, a bidimensional slip and dilation tendency analysis was performed for the identified lineaments after the remote sensing analysis, to evaluate their potential as fluid flow paths.

\subsection{Remote sensing}

An area of $1800 \mathrm{~km}^{2}$ was surveyed, using $12.5 \mathrm{~m}$ digital elevation models (DEMs) from Palsar RTC (https://asf.alaska.edu/). Mesoscale morphological lineaments were identified using a semi-automatic technique (Giordano et al., 2013). This method consists in processing DEMs using Quantum-GIS software, generating hillshade layers (HillShade Function) in eight different azimuth light directions (Sun angular direction) each $45^{\circ}$ of strike. HillShade Function provides a hypothetical shading, respect the light direction which emphasizes perpendicularly oriented lineaments. Then, the Aspect Function is overlapped to create eight slope direction classes, distributed at $\pm 22,5^{\circ}$ respect every generated hillshade layer, and using the same colors for each class in all hillshades. Flat areas and classes facing the opposite sense of the lighting direction, together with the two adjacent classes, were blanked in each filtered image, to facilitate the identification of lineaments defined by colors with similar orientations. Since lineaments observed at more than one light azimuth are mapped several times, we manually clean the database to obtain only one trace for each lineament.

The mesoscale lineaments were analyzed according to their strike using a length weighted rose diagram.

\subsection{Kinematic analysis and fractures sampling}

The kinematic analysis was accomplished measuring different types of kinematic indicators (as slickensides, crystal fibers on slip planes, and associated Riedel fractures) on outcrop-scale faults (Fig. 3A, B and C), following the recognition criteria of Petit (1987) and Doblas (1998). Three stations were selected: (i) Vergara Pass Hill (VPH), immediately to the north of the PPVC; measured faults affect volcanic and volcaniclastic rocks of the Abanico Formation (Figs. 2 and $3 \mathrm{~A}$ and B). (ii) The Azufre River Valley (ARV) and (iii) Peñon River Valley (PRV); these last two sites are located at the PPVC eastern flank (Fig. 2), where kinematic data were measured on Pleistocene to Holocene volcanic and volcaniclastic rocks. After a visual inspection, P-T dihedra method (Angelier and Mechler, 1977) was applied to select the maximum number of fault-slip data that are kinematically compatible in each station, separating the dataset in compatible subsets. Principal strain axes have been computed using the Bingham Statistical Distribution, implemented in FaultKin 


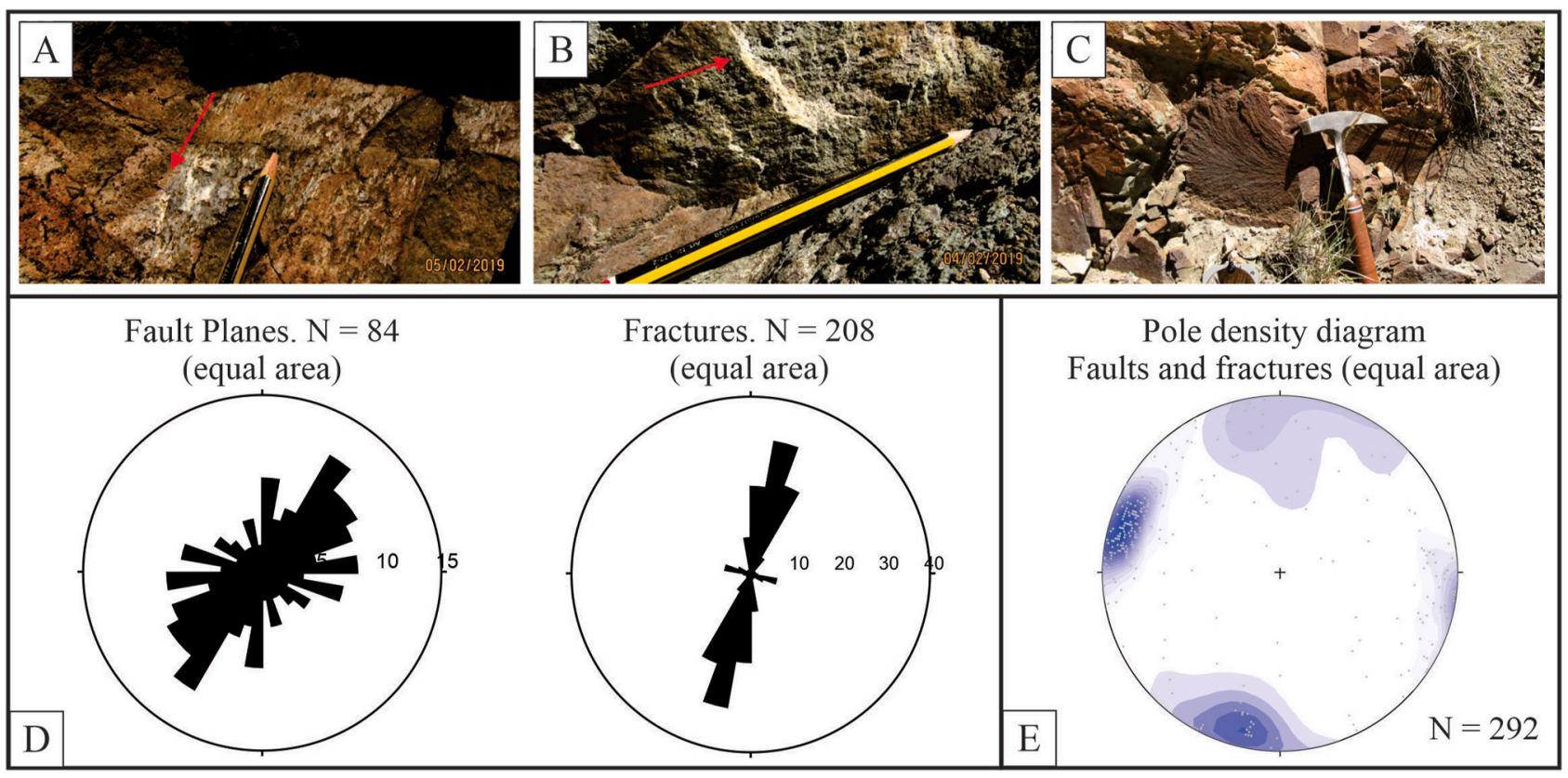

Fig. 3. A) Mineral fibrous growth and B) Steps and striation in Abanico Formation. C) Measured fractures on limestone of Lotena Group, in ARV. Red arrow indicates the kinematic sense. D) Rose diagrams indicate main orientations: fault planes represent the three sites data integration, and measured fractures only in ARV. E) Pole density diagram of faults and fractures population. (For interpretation of the references to color in this figure legend, the reader is referred to the Web version of this article.)

(Marrett y Allmendinger, 1990; Allmendinger et al., 2012). The principal axes of shortening (P), null/intermediate (B) and extension (T) for the incremental strain tensor were obtained, along with an average kinematic fault plane solution for each fault-slip population.

As VPH fault data were measured on structures that affect deformed rocks of the Abanico Formation, we evaluate the results consistency in both current (deformed) and unfolded state to determine their post or pre deformation origin. This test was not necessary for VPH and ARV stations, where measurements were taken on sub-horizontal Pleistocene-Holocene lavas. Additionally, 208 fracture orientations were collected around the main geothermal springs of ARV, on limestone pavements of the Lotena Group (Fig. 3C). A large majority are nearly vertical, suggesting they were also formed after block tilting (Hancock, 1985).

\subsection{Stress inversion}

The data sets obtained from the kinematic analysis, characterized as post-folding and that passed the compatibility test were inverted for stress using the Win-TENSOR software (Delvaux, 1993). The results provided the orientations of the principal stress axes $\sigma_{1}$ (maximum compression), $\sigma_{2}$ (intermediate compression) and $\sigma_{3}$ (minimum compression) and the ratio of principal stress differences $R=\left(\sigma_{2}-\right.$ $\left.\sigma_{3}\right) /\left(\sigma_{1}-\sigma_{3}\right)$ for the youngest recorded deformation event. The four parameters are determined by using an improved version of the Right Dihedral method of Angelier and Mechler (1977), and a four-dimensional numeric rotational optimization method (Delvaux, 1993). This last step involves testing some stress tensors on all faults of the data set to simultaneously minimize the slip deviation $(\alpha)$ for slickensides, maximize the shear stress $(\tau)$ and minimize the normal stress magnitude $\left(\sigma_{\mathrm{n}}\right)$ on each fault plane. Under these conditions, slip on a pre-existing rock discontinuity will occur, in agreement with Amonton's Law. The sliding criteria assume that the friction angle $\varphi$ must be greater than the initial friction angle $\left(\varphi_{0}=16.7^{\circ}\right)$ and smaller than the maximum friction angle $\left(\varphi_{\max }=40.4^{\circ}\right)$, using the values given by Byerlee (1978). It is important to note that the stress magnitudes are expressed relatively because the absolute values cannot be determined using geological data only (Angelier, 1994). In the iterative approach for stress tensor determination, data are excluded by the misfit parameter $\alpha$ using a threshold value of $45^{\circ}$ (recommended for fault-slip data), concerning the stress model parameters that best fit the entire set of data. Excluded data are not discarded but submitted to a new stress tensor calculation, progressively splitting the original data into subsets containing data compatible with the stress model calculated for each subset. Finally, incompatible data are discarded.

The ranking parameter $\mathrm{Q}$ ranges from A (high reliability) to E (low reliability); and is determined as a function of threshold values of a series of criteria (Sperner et at. 2003), namely the total number of fault data measured (nt), the number of fault data used for the stress tensor determination ( $\mathrm{n}$ ), the main slip deviation $(\alpha)$ and the slip sense confidence level for individual faults. Tensors from sites where more than one subset of fault data have been identified have lower ranks than single stress tensor sites, for the same amount of data, being the quality of the calculated tensors greatly influenced by this factor. The stress regime index $\mathrm{R}^{\prime}$ is determined based on the stress ratio $\mathrm{R}$ and the most vertical stress axis in the forms of a continuous scale from 0 (radial extension) to 3 (constriction), with $\mathrm{R}^{\prime}=\mathrm{R}$ for normal faulting regimes $(0-1) ; \mathrm{R}^{\prime}=2-$ $\mathrm{R}$, for strike-slip regimes (1-2); and $\mathrm{R}^{\prime}=2+\mathrm{R}$, for thrust faulting regimes (2-3) (Delvaux and Sperner, 2003).

\subsection{Slip and dilation tendency analyses}

Based on the local obtained paleostress tensor, we performed slip and dilation tendency analysis for the interpreted structural lineaments. Slip (Ts) and dilation (Td) tendencies are understood as the likelihood of a plane to slip and to dilate under an applied stress state, respectively (Hobbs et al., 1976; Ferrill et al., 1999; Morris et al., 1996; Lisle and Srivastava, 2004). Thus, the analysis is based on the decomposition and projection of the local principal stresses $\sigma_{1}, \sigma_{2}, \sigma_{3}$ on faults and fracture planes, neglecting local stress field variations. The $2 \mathrm{D}$ equivalent of $\mathrm{Ts}$ and $\mathrm{Td}$ acting on a linear fracture segment can be computed with FracPaq (Healy et al., 2017), using the two principal stresses and the orientation of one of them.

Combining Coulomb frictional-failure theory (e.g. Jager and Cook, 
1979) with laboratory-derived coefficients of friction ( $\mu$; Byerlee, 1978) leads to the conclusion that the brittle strength of faults and fractures distributed throughout the upper crust limits the maximum differential effective stress (Jaeger and Cook, 1979; Zoback and Townend, 2001):

$\sigma_{1}^{\prime} / \sigma_{3}^{\prime} \leq\left[\left(\mu^{2}+1\right)^{1 / 2}+\mu\right]^{2}$

Using Eq. (1) and values of frictional coefficient of 0.8, 0.6 and 0.4, in agreement with laboratory measurements (Byerlee, 1978; Jaeger and Cook, 1979), we constrain $\sigma_{1}{ }^{\prime} / \sigma_{3}$ ' ratios between 4.33 and 2.18. Given that the slip and dilation tendencies obtained did not show significative differences, we present here the results derived using $\mu=0.6$, and therefore a $\sigma_{1}{ }^{\prime} / \sigma_{3}$ ' ratio of 3.11 .

The $2 \mathrm{D}$ approach adopted here relies on the assumption that we are characterizing sub-vertical structures, and it is only valid under this premise. The projection of the stress components on dipping planes would generate significant changes in the obtained results. A more realistic 3D analysis of faults and fractures would further require knowing the 3D geometry of each of them, and calculate the likelihood of each plane to slip and to dilate. Therefore, the assumption required in the approach presented here necessarily implies a generalization. It permits, however, a significative increase on the extent of a performed analysis (8428 mesoscale lineaments were subjected to these calculations, covering an area of $1800 \mathrm{~km}^{2}$ ), allowing a preliminary characterization of the surficial structures as potential fluid conducts. Obtained results are better supported where field constraints validate that the analyzed families of structural lineaments correspond with sub-vertical structures, as will be discussed later for each structural trend. Furthermore, we restrict the scope of the obtained results to shallow depths, on the upper and steeper parts of the faults and associated damage zones.
Both Td and Ts, which vary between 0 and 1 , were represented on maps and rose diagrams. High values indicate a greater likelihood of failure or dilate and, therefore, likely to shallow circulation of geothermal fluids (Siler et al., 2016).

\section{Results}

\subsection{Lineaments detection}

A total of 8428 mesoscale lineaments were identified by applying the above-described method. The length weighted rose diagram of Fig. 4B shows three notorious trends, which almost double the base value of $2 \%$ in the other directions: $\sim \mathrm{E}-\mathrm{W}$; $\sim \mathrm{NE}-\mathrm{SW}$; and $\sim \mathrm{NW}$-SE. Map of Fig. $4 \mathrm{~A}$ reveals that first-order river valleys are $\sim \mathrm{NW}$-SE oriented, conformed by the alignment of mesoscale lineations of roughly the same trend. These major features are usually deflected forming shorter $\sim \mathrm{E}-\mathrm{W}$ segments giving rise to left bends along their strike. This geometry is well expressed in the Teno River and Colorado River lineaments (Fig. 4A). A more complex setting is observed on the central part of the map, where Los Cajones-Rio Claro lineaments deflect $\sim$ ESE by Del Planchón system that crosses the northern slope of the PPVC. To the south, it is relieved by three $\sim$ E-W trending $\sim 5 \mathrm{~km}$ length traces (Peñón River, Azufre River and Del Cura lineaments), resulting in a through-going right step-over system (Fig. 4A). The NNE-SSW segment of the El Fierro-thrust and the Grande Valley lineaments, together with $\sim$ NE-SW trending lineaments with a more scatter distribution, compartmentalize these structures (Fig. 4A). Some $\sim$ NE-SW mesoscale lineament converge to elbows between the described NW-SE to E-W inflections (e.g., Teno River, Rio Claro-Del Planchón, Colorado River).

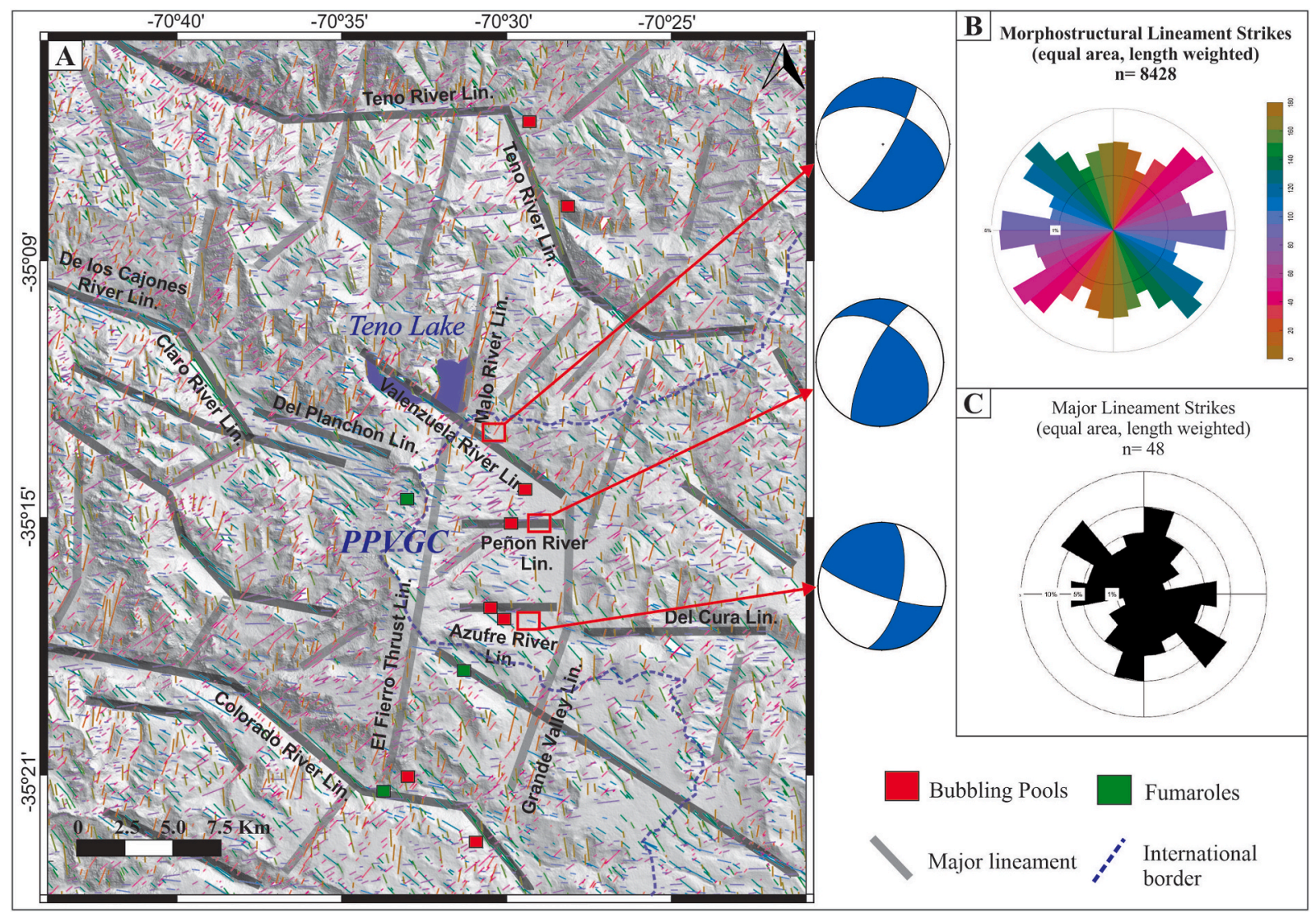

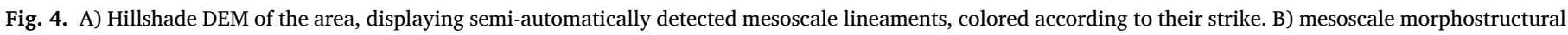

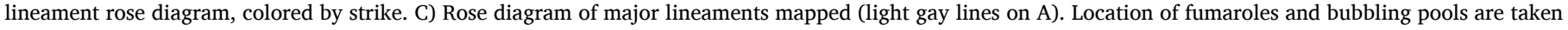
from Benavente (2015), Aguilera et al. (2016), Tassi et al. (2016). 


\subsection{Kinematic analysis and fracture directions}

Rose diagrams and density plots of surveyed faults and fractures (Fig. 3D) show the principal identified outcrop-scale structural directions, affecting different Cenozoic units of the study area. A main NE-SW orientation, and secondary N-S to NNE, $\sim$ E-W and NW to WNW orientations are recognized from the 84 faults database. The fracture pattern surveyed in ARV station (208 fractures) is formed by a principal NNE-SSW orientation, accompanied by a secondary WNW-ESE trending one. Most surveyed structures are highly inclined to sub-vertical (Fig. 3E).

An outline of the kinematics of the whole fault-slip data (see Table A.1 in Appendix A) is presented below, before analyzing individual stations. The dominant, NE-SW fault population is formed by strike-slip dextral faults, associated with few normal and reverse dip-slip faults with minor lateral movements. N-S to NNE oriented faults also present dominant dextral displacements, together with few normal and reverse dip-slip faults. Normal faults prevail for the $\sim \mathrm{E}-\mathrm{W}$ direction group, with subordinated strike-slip components. Finally, the WNW-ESE to NW-SE trend is homogeneously formed oblique-slip sinistral/reverse faults. (see Table A.1 in Appendix A).

The kinematic analysis performed for each station of the study area is summarized in Fig. 5. After evaluating a dataset of 49 faults in the VPH site, two compatible sub-populations were obtained, with 27 faults in the sub-population I and 18 faults in sub-population II. The remaining four faults were discarded due to their dispersion. The two sub- populations of faults found were analyzed to unravel their relative chronology with folding (Fig. 5). This evaluation is only needed for the case of VPH station, measured on tilted rocks of Abanico Formation; the other two stations (PRV and ARV) are placed on sub-horizontal Pleistocene-Holocene volcanic rocks. After comparing the kinematic results in the deformed (current) and unfolded state, the individual $\mathrm{P}$ and $\mathrm{T}$ axes of the sub-population I of faults show a better fit to the kinematic solution in the present-day position, indicating that they likely post-date folding. This strain solution reveals an ENE-WSW shortening direction (azimuth $80^{\circ}$ ) with right-lateral/normal displacement on the NNE fault plane solution, and a left-lateral/reverse displacement on an NW-SE fault plane solution (Fig. 5). As will be shown later, this strain field is consistent with those found in both PRV and ARV stations, supporting that they are registering the younger deformation event affecting the area.

Faults of the sub-population II of VPH in turn show a better P-T-axes consistency with the solution after unfolding the data, indicating that they were likely generated before folding. The fault kinematics indicate subhorizontal shortening with an average $143^{\circ}$ azimuth, with perpendicular subvertical extension (Fig. 5). As will be briefly discussed later in section 5, these ancient faults would (Ferrill et al., 1999) have formed during, or just prior to the late Eocene compressional episode (Mosolf et al., 2019).

In the case of the PRV station, 19 of the 24 measured faults gave rise to a compatible solution; the discarded data were dispersed, considered as the result of sampling bias. Fault kinematics indicates a subhorizontal

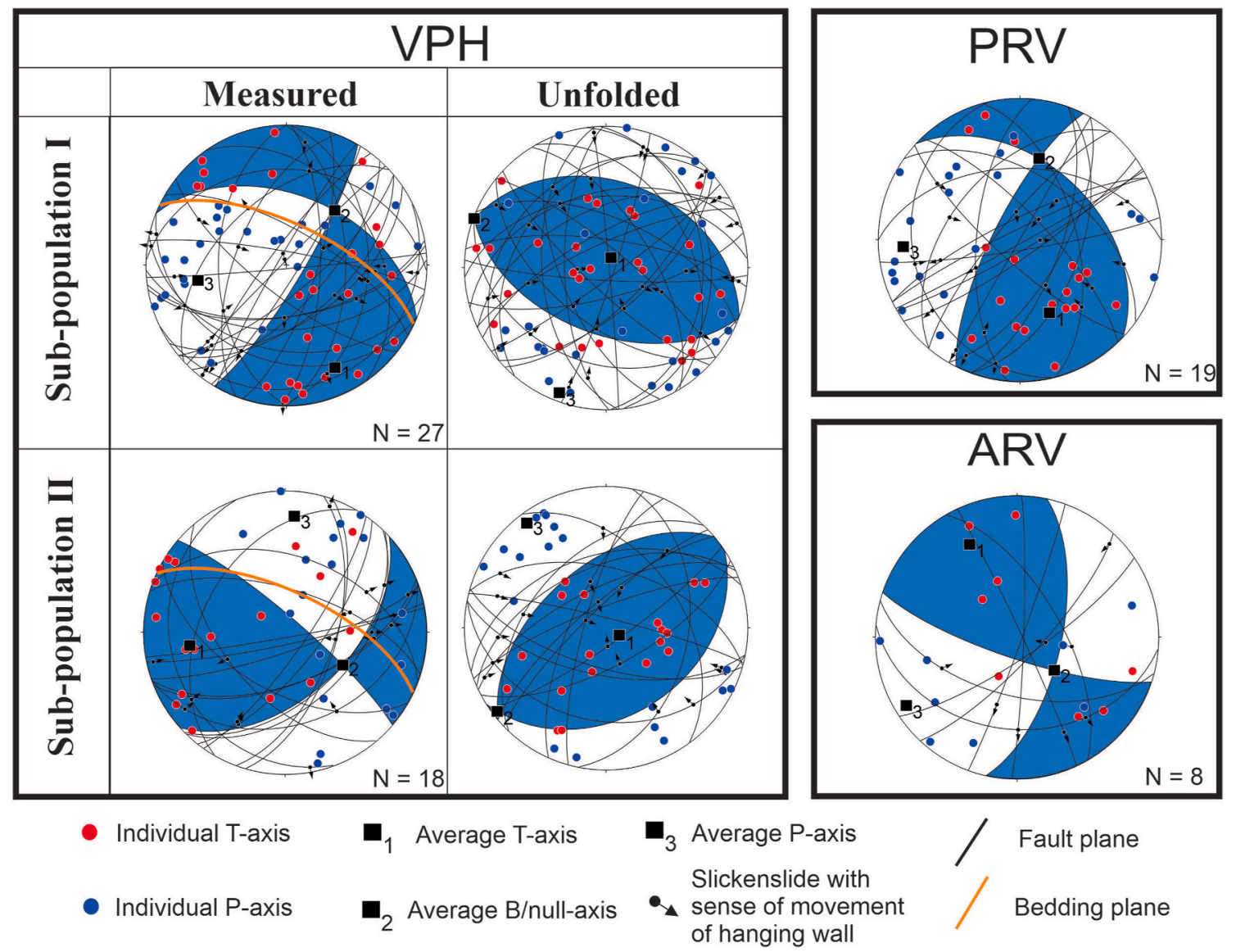

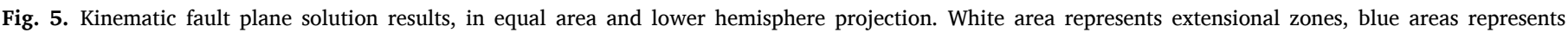

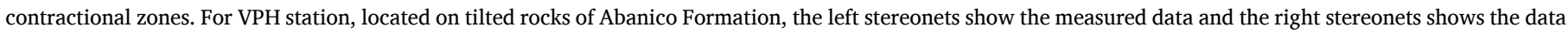

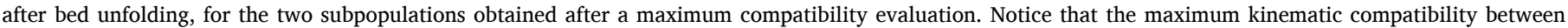

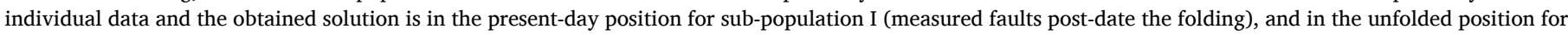

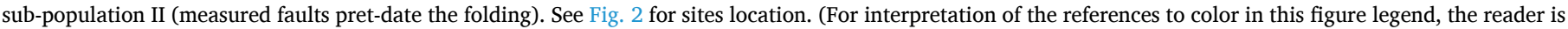
referred to the Web version of this article.) 
ENE-WSW shortening direction (azimuth $87^{\circ}$ ), consistent with the postfolding deformation event registered in VPH. It is associated with a reverse/right-lateral solution on the NNE direction (Gonzalez-Contreras, 2008) and reverse/left-lateral solution in the NW direction.

Finally, in ARV (Marrett and Allmendinger, 1990) station 8 from a total of 11 faults are kinematically compatible. The solution reveals a subhorizontal shortening with an average $58^{\circ}$ azimuth, slightly (Pritchard et al., 2013) counter-clockwise rotated with respect to the shortening direction obtained for PRV station and the post-folding sub-population I of VPH station. As in PRV station, the fault plane solution denotes strike-slip kinematics, with a right-lateral/reverse NNE fault and a left-lateral/reverse WNW fault plane. Despite the small dataset, individual data have a satisfactory fit with (Sperner et al., 2003) the solution, with one P-axes plotting out of the contractional field and two T-axes plotting out of the extension field. The good consistency found between sites compensates for the lack of robustness of this station.

Further, the fractures survey performed in this same site reveals an apparent strike clustering, defining two fracture sets with NNE-SSW and WNW-ESE orientations, mostly subvertical (Fig. 3E). As can be observed in Figs. 3 and 5, both faults and fractures populations share the same main directions.

\subsection{Stress inversion results}

The stress inversion results are reported in Table 1 and detailed in Fig. 6. For each station, after the iterative approach for stress tensor determination, some data are excluded by the misfit parameter to get the best fit with the largest set of data. When more than 4 faults were excluded, they were not discarded but submitted to a new stress tensor calculation to generate a solution for this subset. However, this was only the case for the post-folding sub-population of VPH station, while for the other two stations the low amount of excluded data prevented to infer other stress models, and were discarded (for further discussion, see Delvaux, 1993).

The 27 post-folding faults of VPH station (sub-population I) define two rather similar paleostress solutions, with ENE-WSW directed $\sigma_{1}$ for the first subset $(\mathrm{N}=10)$ and NE-SW directed $\sigma_{1}$ for the second subset $(\mathrm{N}$ $=8$ ). Both have a subvertical $\sigma_{2}$, and their $\mathrm{R}^{\prime}$ values define pure strike$\operatorname{slip}\left(R^{\prime}=1.48\right)$ and transtensive $\left(R^{\prime}=1.19\right)$ stress regimes, respectively (Fig. 6). Also, for VPH-1 $\sigma_{1}$ orientation is coincident with the principal axes of shortening (P) obtained in section 4.2 (Fig. 5).

After processing 19 kinematically compatible faults of PRV station, 10 faults best fit the resulting paleostress with a NE-SW orientation of the $\sigma_{1}$, a subvertial $\sigma_{2}$, and an NW-SE orientation of $\sigma_{3}$. The R' value (1.36) define pure strike-slip, with a " $\mathrm{C}$ " quality rank given by the number of compatible data with the stress model relative to the total.

Finally, 6 of 8 kinematically compatible fault-slip data from ARV are consistent with a transpressive stress regime $\left(\mathrm{R}^{\prime}=1.94\right)$, with a similar orientation of the stress tensor than PRV. The NE-SW orientation of SHmax is coincident with the principal axis of shortening (P) obtained in section 4.2 (Fig. 5).

The results presented in this section are consistent with a strike-slip regime of NE to ENE maximum compressive direction, being the mean $\sigma_{1}=60^{\circ}$. However, it is important to bear in mind that the obtained solutions are based on small amounts of data, which lowers its quality; this is usually a problem in Pliocene-Quaternary fault-slip analysis. Despite this, the consistency of the paleostress regime obtained between our three stations, and with results from nearby regions taken from the bibliography, compensate for this lack of robustness. This will be further discussed in section 5 .

\subsection{Slip and dilation tendencies}

Combining the results of sections 4.1 and 4.3, we carried out 2D slip and dilation tendency analyses over 8428 mesoscale interpreted morphostructural lineaments. Despite the limitations described for the paleo-stress determination, we rely on the agreement found between stations for the younger stress regime and obtained tensor orientations, strongly backed by the more robust database of the nearby Tinguiririca area (Giambiagi et al., 2019). Therefore, a mean NE-SW SHmax orientation $\left(60^{\circ}\right)$ is assumed for the slip and dilation tendencies calculations. As explained in section 3.3, according to the frictional equilibrium (Eq. (1)) we estimate a $\sigma_{1}, / \sigma_{3}$ ' ratio of 3.11 , assuming $\mu=0.6$.

Under this stress state, NNE-SSW and E-W structural orientations have a relatively high slip tendency. On the other hand, NW-SE and NESW trending morphostructural lineaments are unfavorably oriented for slip (Fig. 7).

Structural lineaments sub-parallel to SHmax (NE-SW) register the highest dilation tendencies, and those within the range spanning from NNE-SSW to E-W trends are above a 0.7 threshold value. On the other hand, NW-SE trending structures are unlike to dilate under this stress regime (Fig. 7).

It is interesting to note that first-order structural lineaments that crosscut the mapped area are shaped by many equally oriented smallerscale traces (Figs. 4, 7 and 8). To the south, along with the Rio Colorado, a left inflection of the main $\sim$ NW-SE trend of the valley gives rise to a highly slip and moderate dilatational $\sim$ E-W segment, where the Baños de Llolli thermal area is placed. The Azufre and Peñon geothermal manifestations are also placed over $\sim \mathrm{E}-\mathrm{W}$ trending lineaments, with high associated slip and dilation tendencies (Azufre River Valley and Peñón River Valley lineaments). All the manifestations are located east of the $\sim$ NNE-SSW trending El Fierro-thrust Lineament, reported at this latitude as regional faults with dips $\geq 45^{\circ}$ (González-Contreras, 2008; Benavente, 2015; Mosolf et al., 2019). High slip and moderate dilation tendency are obtained for these NNE-SSW oriented structures (Figs. 7 and 8). We might expect this group of faults to be steep next to the surface, as reported by Giambiagi et al. (2019) for the same family of structures in the nearby Tinguiririca geothermal field. These authors report that a close direct relation exists between fault dip and the slip/dilation tendency for the NNE-trending reactivated reverse faults of this area, with high values of slip tendency distributed on their upper and steeper sections.

As explained in section 3.4, the directional results of the slip and dilation tendencies reported here are limited by the adopted 2D approach, and constitutes therefore a preliminary structural characterization restricted to shallow depths, where steeper parts of structures prevail. In order to assess the validity of assuming that the analyzed

Table 1

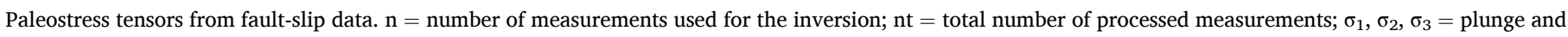

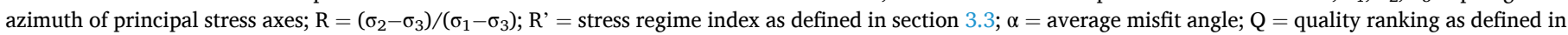
section 3.3.

\begin{tabular}{|c|c|c|c|c|c|c|c|c|c|c|c|}
\hline Configuration & location & $\mathrm{n}$ & nt & $\sigma_{1}$ & $\sigma_{2}$ & $\sigma_{3}$ & $\mathrm{R}$ & $\mathrm{R}^{\prime}$ & A & Stress Regime & Quality \\
\hline \multicolumn{12}{|l|}{ Stress Tensors } \\
\hline VPH-1 & $35^{\circ} 12^{\prime} \mathrm{S}$ & 10 & 27 & 08/079 & $54 / 337$ & $34 / 174$ & 0.52 & 1.48 & 35 & Pure STRIKE-SLIP & $\mathrm{C}$ \\
\hline VPH-2 & $70^{\circ} 31^{\prime} \mathrm{W}$ & 8 & 27 & $11 / 224$ & $79 / 047$ & $01 / 314$ & 0.81 & 1.19 & 36.1 & Extensional STRIKE-SLIP & $\mathrm{E}$ \\
\hline PRV & $35^{\circ} 14^{\prime} \mathrm{S} 70^{\circ} 30^{\prime} \mathrm{W}$ & 10 & 19 & $5 / 239$ & $51 / 335$ & $38 / 145$ & 0.64 & 1.36 & 31.8 & Pure STRIKE-SLIP & $\mathrm{C}$ \\
\hline ARV & $35^{\circ} 17^{\prime} \mathrm{S} 70^{\circ} 30^{\prime} \mathrm{W}$ & 6 & 8 & $21 / 241$ & $56 / 006$ & $26 / 241$ & 0.26 & 1.94 & 24.4 & Compressive STRIKE-SLIP & $\mathrm{D}$ \\
\hline
\end{tabular}



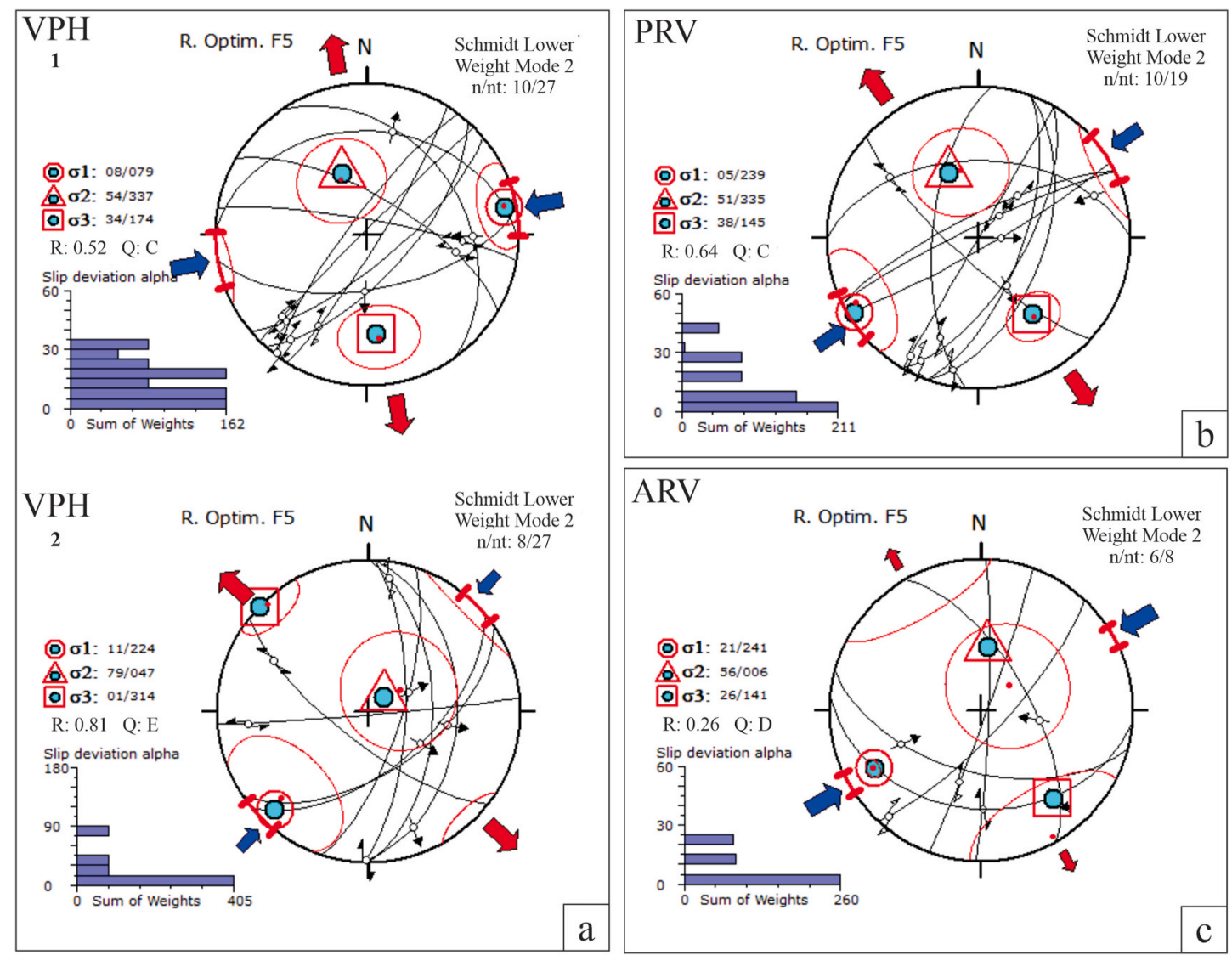

Fig. 6. Stress inversion results. Lower-hemisphere Schmidt stereoplot of the fault-slip data subsets and corresponding stress tensor. Histogram of weighted misfit function. Horizontal stress symbols: Blue narrows are sigma 1, and red narrows are sigma 3. (For interpretation of the references to color in this figure legend, the reader is referred to the Web version of this article.)

groups of structural lineaments correspond to sub-vertical structures, we need to indirectly correlate them with the data acquired during the field survey. The $\sim$ NNE-SSW and $\sim$ E-W structural orientations correspond well with sub-vertical measured structures (Fig. 3E), validating the performed calculations with the $2 \mathrm{D}$ approach. On the other hand, $\sim \mathrm{NW}-$ $\mathrm{SE}$ and $\sim \mathrm{NE}-\mathrm{SW}$ directions present more variability in the measured inclinations, while some sub-vertical dips were surveyed (Fig. 3E). Although we are aware of the indirect nature of these evidences, considering that this geothermal project is in an early exploration phase, without studies to date addressing the role of general fracturing and faulting pattern on the geothermal shallow fluid circulation, results presented provide a useful initial approach.

\section{Discussion}

Kinematic results were obtained after processing outcrop-scale faults-slip data affecting Cenozoic units from three different structural stations. VPH station, measured in Eocene rocks, shows two superimposed strain fields. The pre-folding solution presents a horizontal NW-SE trending shortening axis, and a perpendicular subvertical extension axis (Fig. 5). These ancient faults would have formed during, or just prior to the late Eocene compressional episode (Mosolf et al., 2019), probably affected by $\sim$ NE-SW striking weakness zones inherited from the pre-existing structural architecture of the Andean basement at these latitudes (Piquer et al., 2019, Fig. 4A). However, with small sample size and a single measure station, further work is needed to assess this early deformation event, which is out of the scope of the present work. The post-folding solution of this station, together with the best solutions obtained on sub-horizontal Pleistocene-Holocene volcanic rocks of ARV and PRV stations, indicate strike-slip kinematics (Fig. 5), likely active during the Quaternary, with ENE to NE contraction directions and fault planes striking $\sim$ NW (left-lateral) and $\sim$ NE (right-lateral). These solutions are supported by compatible strike-slip focal mechanisms reported near the study area by several authors. Spagnotto et al. (2015) presented local dextral strike-slip mechanisms (Fig. 1; GCMT database), associated with NNE-trending dextral strike-slip faults (Farías, 2007; Comte et al., 2008); and Villegas et al. (2016) obtained a reverse/strike-slip solution for the same fault system.

The local stress fields determined after the paleostress analysis of the younger deformation event affecting this area are consistent with a strike-slip regime, with a NE to ENE trending $\sigma_{1}$, subvertical $\sigma_{2}$, and NWSE to NNW trending $\sigma_{3}$ (Fig. 6, Table 1). Although the solution obtained is based on small amounts of data, which lowers its quality, it is consistent with the paleostress regime determined in nearby regions, compensating this lack of robustness. Based on crustal earthquakes in the Andean arc between $35^{\circ} \mathrm{S}$ and $36^{\circ} \mathrm{S}$, Spagnotto et al. (2015) point out that the Quaternary stress regime would be strike-slip, with SW-oriented $\sigma_{1}$ and $\sim \mathrm{NW}$-oriented $\sigma_{3}$. Likewise, Giambiagi et al. (2019) reported a regional strike-slip stress regime with $\sim$ ENE oriented SHmax based on a large fault-slip database over the nearby Tinguiririca geothermal system, showing a good agreement with our results. Also, the obtained SHmax orientation is consistent with the shortening direction estimated from the kinematic modeling of GPS data (Métois et al., 2012), and it is sub-parallel to the maximum horizontal stress direction informed by Guzmán et al. (2007), based on borehole breakouts in the foreland.

Although more work is needed to fully assess the stress field and its local variations in our study area, we suggest that a strike-slip stress regime would have been taking place at least since the Holocene. Leading oblique to the orogen lineaments with linked strike-slip 


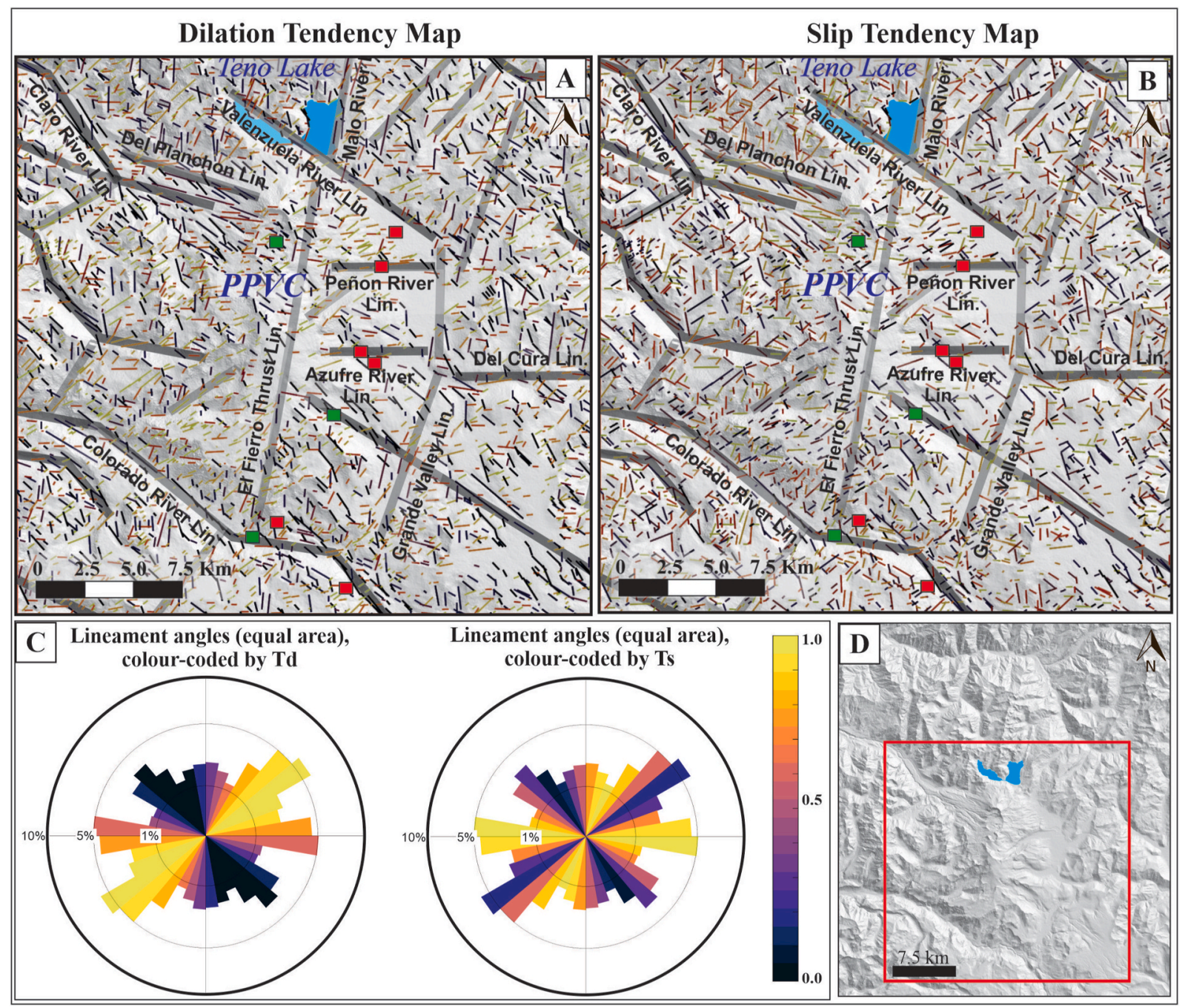

Fig. 7. A) Dilation tendency (A) and slip tendency (B) $2 D$ analysis for the interpreted structural lineaments; results for NE-SW oriented $\sigma_{1}\left(60^{\circ}\right)$ and $\mu=0.6$. The chromatic scale for both analyses is at Fig. 7C. Green filled squares are fumaroles and red filled square are bubbling pools, from Benavente (2015), Aguilera et al. (2016), and Tassi et al. (2016). Light grey lines are major lineaments. C) Equal area rose plot of segment orientations color coded by dilation and slip tendency. D) Hillshade DEM with the location of the analyzed area. (For interpretation of the references to color in this figure legend, the reader is referred to the Web version of this article.)

kinematic solutions (Fig. 4) appears as a result of this process, likely favoured by the heritage of ancient $\sim$ NW-SE and $\sim$ NE-SW structures (Piquer et al., 2019; Sielfeld et al., 2019). This setting could have significant effects on fluid circulation. A strong directional permeability is expected parallel to $\sigma_{2}$, promoting the migration of fluids through a mesh of shear and extension fractures (Hill, 1977; Sibson, 1996). Under the strike-slip regime that governs deformation, this direction is vertical, favouring fluid circulation from above the magma chamber into the shallower crustal levels.

Previous studies highlight the sub-meridional El Fierro fault system as the main structures controlling the deformation style of this region (e. g., Farías et al., 2010; Tapia et al., 2015). The damage zone associated with this and other NNE-striking faults have been considered to play a significant role in fluid mobility in the Tinguiririca Volcanic Complex, $50 \mathrm{~km}$ north from the working area (Pavez et al., 2016; Giambiagi et al., 2019). Further south from our study area, in the Tatara-San-Pedro-Pellado Volcanic Complex of the Southern Volcanic Zone $\left(36^{\circ} \mathrm{S}\right)$, WNW- to ENE-oriented structures under a transtensional stress field define fault-controlled geothermal fluid pathways, giving rise to geothermal manifestations at the surface (Sielfeld et al., 2019). At the PPVC, an explicit spatial relation is observed between oblique NW-SE structurally controlled valleys and the associated $\sim$ E-W inflections, and geothermal manifestations at the surface.
As can be observed in Fig. 7, PRV and ARV geothermal manifestations are located over $\sim \mathrm{E}-\mathrm{W}$ lineaments; all of them are constricted between the main NNE-striking El Fierro-thrust and Grande Valley lineaments. These manifestations (bubbling pools and fumaroles) occur in a $\sim$ NNE trend, subparallel to the El Fierro fault system (Fig. 1). Our investigations indicate that smaller-scale structures with higher than 0.7 values of dilation tendency (NE to ESE trends) and slip tendency (N-S to NNE and E-W to ESE trends), may have provided pathways for hot fluid migration within these damage zones next to the surface (Fig. 8). The intersections zones between meridional and transverse structures correspond to areas of maximum damage, enhancing fracturing and reopening of fluid conduits. This process is shown in a variety of studies (e.g., Curewitz and Karson, 1997; Marten and Boger, 1998; Sibson and Rowland, 2003) and reported along the high Andes of Chile between $33^{\circ}$ and $34.5^{\circ} \mathrm{S}$ as main structural controls on magmatic and hydrothermal activity (Piquer et al., 2019). Our outcomes agree well with the 3D model from Giambiagi et al. (2019) for the Tinguiririca geothermal field, where major NNE-striking faults controlling the hydrothermal system present high values of slip tendency distributed on the upper and steeper parts of the faults, connected by second-order subvertical W-E to ESE striking structures, with very high dilation tendency.

However, as was explained in this paper, it is important to bear in mind the bidimensional character of our slip/dilation tendency analysis, 


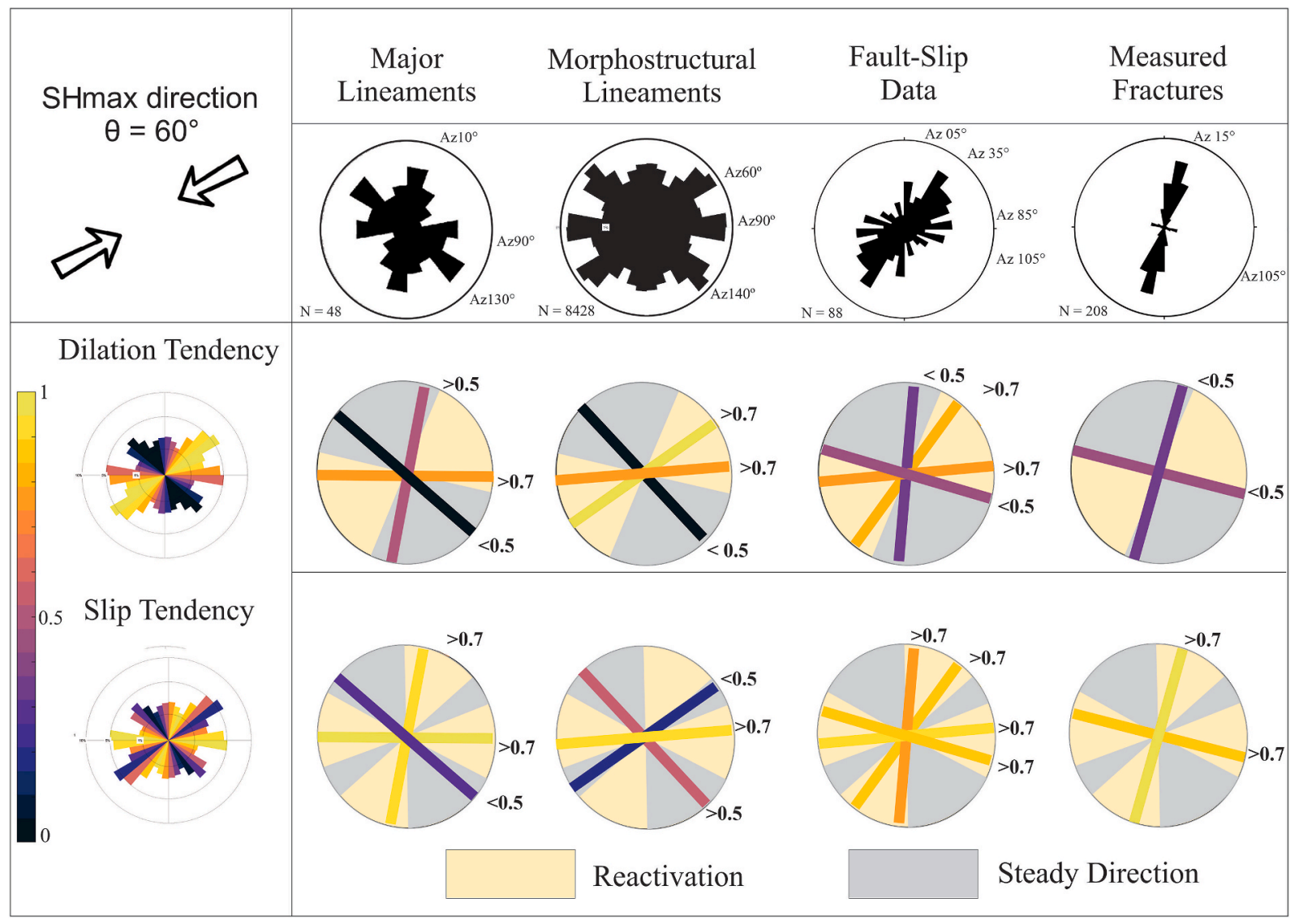

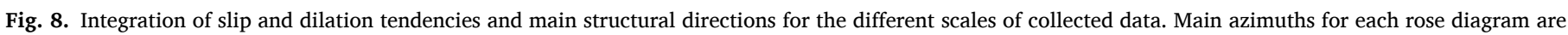

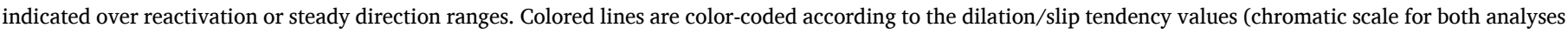
is at left of the figure). (For interpretation of the references to color in this figure legend, the reader is referred to the Web version of this article.)

which imposes caution to assess the behaviour of each family of structures. We raise these outcomes as a preliminary structural characterization restricted to shallow depths, where steeper parts of structures prevail, given that we cannot extrapolate our 2D characterization to dipping structures. Although some groups of the interpreted structural lineaments were correlated with sub-vertical faults and fractures families acquired during the field survey, we acknowledge that this correlation does not fully validate the 2D approach. However, the applied approximation permitted to generate a large dataset covering a broad area (8428 mesoscale lineaments spread over $1800 \mathrm{~km}^{2}$ area), which constitutes significant progress as part of an early exploration phase of the geothermal project to address the role of general fracturing and faulting pattern on the geothermal shallow fluid circulation.

\section{Conclusions}

The present study aims to characterize the structural setting of the Planchón-Peteroa Volcanic Complex and better explore the spatial relationship between faults and fractures, local stress state, and active hot springs.

For this purpose, we investigate the local fault stress in the principal zones of geothermal manifestations. Four compatible paleotensors were obtained after kinematic inversion of fault-slip data, evidencing a strikeslip regime with ENE-WSW to NE-SW oriented $\sigma_{1}$, subvertical $\sigma_{2}$, and an NW-SE $\sigma_{3}$, probably active since the Pleistocene.

The detection of lineaments from digital elevation models shows that the main orientations correspond to the directions of the principal regional tectonic structures. Major NW-SE trending structurally controlled valleys and associated $\sim \mathrm{E}-\mathrm{W}$ inflections and step-overs crosscutting the study area are identified. These transverse structures exert first-order controls on the location of Peñon River and Azufre River Valleys hydrothermal manifestations. It seems that intersection zones with submeridian structures, as El Fierro Fault System, increase structural damage and facilitate hot fluid migration.

To achieve a first approach on the role of shallow structures on the geothermal fluid circulation, we conduct a bidimensional slip and dilation tendency analysis over the structural directions identified at different scales, under the inferred Quaternary stress field. This method permitted to characterize 8428 mesoscale lineaments spread over an $1800 \mathrm{~km}^{2}$ area, with some underlying assumptions. Results suggest that $\sim$ NNE-SSW and $\sim$ E-W oriented structures have high slip tendency, while NE-SW to ENE oriented structures are prone to dilate. We conclude that fluid circulation would profit the most from $\sim \mathrm{E}-\mathrm{W}$ and $\sim$ NE-SW striking outcrop-scale faults and fractures associated with the mentioned damage zones.

\section{Author statement}

N. Vigide: Conceptualization, Formal analysis, Visualization, Investigation, Writing - Original Draft. D. Yagupsky: Conceptualization, Visualization, Writing - Review \& Editing, Project administration, Funding acquisition. H. Barcelona: Conceptualization, Visualization Writing - Review \& Editing, Funding acquisition. M. Agusto: Writing Review \& Editing, Funding acquisition. A. Caselli: Writing - Review \& Editing.

\section{Declaration of competing interest}

The authors declare that they have no known competing financial interests or personal relationships that could have appeared to influence 
the work reported in this paper.

\section{Acknowledgments}

This research was supported by funding from the Agencia Nacional de Promoción Científica y Tecnológica (projects PICT 2016-2315 and PICT 2015-3110) and Universidad de Buenos Aires (UBACyT 20020170200221BA), Argentina. Careful reviews by José Mescua and an anonymous reviewer of an earlier draft significantly improved the manuscript.

Appendix A. Measured fault-slip data for the three sites

Table A.1

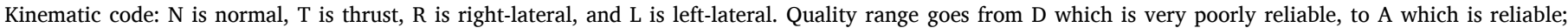
particularly, $\mathrm{S}$ is very reliable (secondary growth). Bedding is expressed in dip/dip-direction. Subh indicates subhorizontal.

\begin{tabular}{|c|c|c|c|c|c|c|c|}
\hline DATA & DIP DIR & DIP & PLUNGE & TREND & KINEMATIC & QUALITY & BEDDING \\
\hline \multicolumn{8}{|c|}{ Site: Azufre River Valley (ARV) } \\
\hline 1 & 105 & 56 & 48 & 63 & TR & C & Subh \\
\hline 2 & 146 & 78 & 72 & 196 & $\mathrm{TL}$ & $\mathrm{C}$ & Subh \\
\hline 3 & 133 & 77 & 8 & 221 & NL & $\mathrm{D}$ & Subh \\
\hline 4 & 92 & 86 & 35 & 179 & NR & A & Subh \\
\hline 5 & 18 & 56 & 14 & 298 & TR & A & Subh \\
\hline 6 & 110 & 87 & 49 & 197 & NR & A & Subh \\
\hline 7 & 195 & 56 & 42 & 247 & $\mathrm{TL}$ & A & Subh \\
\hline 8 & 285 & 87 & 38 & 13 & $\mathrm{TL}$ & A & Subh \\
\hline 9 & 60 & 64 & 58 & 100 & $\mathrm{TL}$ & B & Subh \\
\hline 10 & 185 & 35 & 26 & 139 & NL & $\mathrm{S}$ & Subh \\
\hline 11 & 65 & 87 & 26 & 154 & NR & $\mathrm{C}$ & Subh \\
\hline \multicolumn{8}{|c|}{ Site Peñón River Valley (PRV) } \\
\hline 1 & 150 & 84 & 78 & 91 & NL & B & Subh \\
\hline 2 & 334 & 88 & 82 & 50 & NR & B & Subh \\
\hline 3 & 334 & 84 & 74 & 43 & NL & A & Subh \\
\hline 4 & 110 & 66 & 60 & 150 & NR & B & Subh \\
\hline 5 & 334 & 78 & 59 & 43 & NL & $\mathrm{C}$ & Subh \\
\hline 6 & 120 & 90 & 11 & 210 & NR & $\mathrm{D}$ & Subh \\
\hline 7 & 151 & 88 & 60 & 238 & NR & $\mathrm{C}$ & Subh \\
\hline 8 & 145 & 80 & 22 & 231 & NR & $\mathrm{E}$ & Subh \\
\hline 9 & 171 & 84 & 42 & 256 & NR & $\mathrm{D}$ & Subh \\
\hline 10 & 140 & 80 & 0 & 50 & NL & C & Subh \\
\hline 11 & 257 & 25 & 25 & 257 & $\mathrm{TR}$ & A & Subh \\
\hline 12 & 222 & 77 & 30 & 304 & TL & B & Subh \\
\hline 13 & 300 & 68 & 29 & 223 & NL & B & Subh \\
\hline 14 & 120 & 65 & 11 & 205 & NR & A & Subh \\
\hline 15 & 275 & 65 & 30 & 201 & TR & A & Subh \\
\hline 16 & 80 & 83 & 64 & 155 & TL & A & Subh \\
\hline 17 & 75 & 57 & 36 & 137 & $\mathrm{TL}$ & A & Subh \\
\hline 18 & 35 & 52 & 25 & 103 & $\mathrm{TL}$ & A & Subh \\
\hline 19 & 0 & 48 & 20 & 70 & $\mathrm{TL}$ & A & Subh \\
\hline 20 & 46 & 75 & 38 & 124 & TL & A & Subh \\
\hline 21 & 310 & 49 & 47 & 288 & $\mathrm{TR}$ & A & Subh \\
\hline 22 & 15 & 71 & 47 & 307 & NL & A & Subh \\
\hline 23 & 310 & 78 & 74 & 353 & $\mathrm{TL}$ & A & Subh \\
\hline 24 & 110 & 54 & 12 & 191 & $\mathrm{TR}$ & A & Subh \\
\hline \multicolumn{8}{|c|}{ Site Vergara Pass Hill (VPH) } \\
\hline 1 & 20 & 45 & 36 & 64 & NR & $\mathrm{D}$ & $87 / 150$ \\
\hline 2 & 55 & 36 & 31 & 91 & $\mathrm{TL}$ & A & $87 / 150$ \\
\hline 3 & 300 & 41 & 20 & 234 & TR & B & $87 / 150$ \\
\hline 4 & 291 & 60 & 60 & 291 & TR & $\mathrm{D}$ & $66 / 25$ \\
\hline 5 & 2 & 32 & 31 & 14 & NR & $\mathrm{B}$ & $66 / 25$ \\
\hline 6 & 106 & 60 & 6 & 20 & NL & $\mathrm{C}$ & $66 / 25$ \\
\hline 7 & 161 & 79 & 10 & 73 & NL & A & $66 / 25$ \\
\hline 8 & 158 & 60 & 37 & 94 & TR & A & $66 / 25$ \\
\hline 9 & 192 & 39 & 3 & 278 & NR & $\mathrm{C}$ & $66 / 25$ \\
\hline 10 & 202 & 32 & 5 & 283 & NR & A & $66 / 25$ \\
\hline 11 & 307 & 80 & 2 & 217 & $\mathrm{TR}$ & A & $66 / 25$ \\
\hline 12 & 170 & 60 & 59 & 182 & NR & A & $66 / 25$ \\
\hline 13 & 315 & 88 & 23 & 226 & $\mathrm{TR}$ & A & $66 / 25$ \\
\hline 14 & 135 & 52 & 23 & 65 & NL & A & $66 / 25$ \\
\hline 15 & 178 & 52 & 23 & 248 & NR & A & $66 / 25$ \\
\hline 16 & 132 & 67 & 15 & 216 & NR & A & $66 / 25$ \\
\hline 17 & 42 & 80 & 16 & 315 & $\mathrm{TR}$ & A & $87 / 150$ \\
\hline 18 & 108 & 72 & 66 & 65 & NL & A & $87 / 150$ \\
\hline 19 & 300 & 85 & 83 & 345 & $\mathrm{TL}$ & $\mathrm{C}$ & $87 / 150$ \\
\hline 20 & 30 & 69 & 40 & 101 & $\mathrm{TL}$ & A & $87 / 150$ \\
\hline 21 & 140 & 74 & 23 & 223 & NR & A & $87 / 150$ \\
\hline 22 & 210 & 56 & 34 & 147 & TR & A & $87 / 150$ \\
\hline
\end{tabular}


Table A.1 (continued)

\begin{tabular}{|c|c|c|c|c|c|c|c|}
\hline DATA & DIP DIR & DIP & PLUNGE & TREND & KINEMATIC & QUALITY & BEDDING \\
\hline 23 & 17 & 65 & 50 & 73 & TL & $\mathrm{S}$ & $87 / 150$ \\
\hline 24 & 10 & 82 & 37 & 94 & $\mathrm{TL}$ & A & $87 / 150$ \\
\hline 25 & 160 & 35 & 12 & 233 & $\mathrm{TL}$ & A & $87 / 150$ \\
\hline 26 & 175 & 88 & 21 & 264 & $\mathrm{TL}$ & A & $87 / 150$ \\
\hline 27 & 125 & 78 & 29 & 208 & $\mathrm{TL}$ & A & $87 / 150$ \\
\hline 28 & 218 & 73 & 30 & 298 & TL & A & $87 / 150$ \\
\hline 29 & 317 & 50 & 50 & 326 & NR & $\mathrm{C}$ & $87 / 150$ \\
\hline 30 & 352 & 87 & 72 & 73 & $\mathrm{TL}$ & B & $87 / 150$ \\
\hline 31 & 270 & 50 & 44 & 234 & TR & B & $87 / 150$ \\
\hline 32 & 122 & 83 & 32 & 208 & NR & A & $87 / 150$ \\
\hline 33 & 170 & 87 & 19 & 81 & $\mathrm{TR}$ & A & $87 / 150$ \\
\hline 34 & 110 & 61 & 60 & 98 & TR & B & $66 / 25$ \\
\hline 35 & 140 & 58 & 57 & 122 & NL & A & $66 / 25$ \\
\hline 36 & 250 & 20 & 3 & 169 & NL & $\mathrm{C}$ & $66 / 25$ \\
\hline 37 & 172 & 60 & 44 & 116 & NL & A & $66 / 25$ \\
\hline 38 & 230 & 54 & 53 & 245 & NR & A & $66 / 25$ \\
\hline 39 & 128 & 70 & 28 & 207 & TL & A & $66 / 25$ \\
\hline 40 & 168 & 83 & 5 & 257 & $\mathrm{TL}$ & A & $66 / 25$ \\
\hline 41 & 90 & 55 & 12 & 9 & $\mathrm{TR}$ & A & $66 / 25$ \\
\hline 42 & 92 & 41 & 19 & 159 & $\mathrm{TR}$ & A & $66 / 25$ \\
\hline 43 & 134 & 48 & 39 & 90 & NL & A & $66 / 25$ \\
\hline 44 & 154 & 14 & 7 & 93 & $\mathrm{TR}$ & B & $66 / 25$ \\
\hline 45 & 92 & 70 & 2 & 181 & NR & A & $66 / 25$ \\
\hline 46 & 160 & 60 & 26 & 86 & NL & A & $66 / 25$ \\
\hline 47 & 250 & 44 & 44 & 244 & TR & A & $66 / 25$ \\
\hline 48 & 320 & 65 & 61 & 354 & $\mathrm{TL}$ & A & $66 / 25$ \\
\hline 49 & 146 & 56 & 46 & 100 & NL & A & $66 / 25$ \\
\hline
\end{tabular}

\section{References}

Aguilera, F., Benavente, O., Gutiérrez, F., Romero, J., Saltori, S., González, R., Agusto, M., Caselli, A., Pizarro, M., 2016. Eruptive activity of Planchón-Peteroa volcano for period 2010-2011, southern andean volcanic zone, Chile. Andean Geol. 43 (1), 20-46. https://doi.org/10.5027/andgeoV43n1-a02.

Allmendinger, R.W., Cardozo, N.C., Fisher, D., 2012. Structural Geology Algorithms: Vectors \& Tensors. Cambridge University Press, Cambridge, England, p. 289.

Angelier, J., 1994. Fault slip analysis and palaeostress reconstruction. In: Hancock, P.L. (Ed.), Continental Deformation. Pergamon, Oxford, pp. 101-120.

Angelier, J., Mechler, P., 1977. Sur une méthode graphique de recherche des contraintes principales également utilisable en tectonique et en séismologie: 1a méthode des diédres droits. Bull. Soc. Géol. France 7 (19), 1309-1318.

Arnorsson, S., 1995. Geothermal systems in Iceland: structure and conceptual models: I. High-temperature areas: Geothermics 24, 564-602. https://doi.org/10.1016/03756505(95)00025-9.

Barazangi, M., Isacks, B., 1976. Spatial distribution of earthquakes and subduction of the Nazca plate beneath. South Am. Geol. 4, 606-692.

Benavente, O., 2015. Origen y naturaleza de los fluidos en los sistemas volcánicos e hidrotermales activos de los Andes de Chile Central (32.5-36 $\mathrm{S}$ ). Tesis Doctoral, Universidad de Chile (inédita), Santiago, p. 218.

Bons, P.D., Elburg, M.A., Gomez-Rivas, E., 2012. A review of the formation of tectonic veins and their microstructures. J. Struct. Geol. 43, 33-62. https://doi.org/10.1016/ j.jsg.2012.07.005.

Byerlee, J.D., 1978. Friction of rocks. Pure Appl. Geophys. 116, 615-629.

Caliro, S., Chiodini, G., Galluzzo, D., Granieri, D., La Rocca, M., Saccorotti, G., Ventura, G., 2005. Recent activity of Nisyros volcano (Greece) inferred from structural, geochemical and seismological data. Bull. Volcanol. 67, 358-369. https:// doi.org/10.1007/s00445-004-038-7.

Cande, S., Leslie, R., 1986. Late Cenozoic tectonics of the southern Chile trench. J. Geophys. Res. 91, 471-496.

Cande, S., Leslie, R., 1987. Interaction between the Chile Ridge and Chile Trench: geophysical and geothermal evidence. J. Geophys. Res. 92, 495-520.

Charrier, R., Wyss, A.R., Flynn, J.J., Swisher III, C.C., Spichiger, S., Zapatta, F., 1994. Nuevos antecedentes estratigráficos y estructuralos para las Formaciones CoyaMachalí y Abanico, entre $33^{\circ} 50^{\prime}$ y $35^{\circ} \mathrm{S}$, Cordillera Principal, Chilena. In: Resúmenes del VII Congreso Geológico Chileno: Concepción, Chile, vol. 2. Servicio Nacional de Geología y Minería, Universidad de Chile, Departamento de Geología, Sociedad Geológica de Chile, pp. 1316-1319.

Charrier, R., Wyss, A.R., Flynn, J.J., Swisher, C., Norell, M.A., Zapata, F., McKenna, M.C., Novacek, M.J., 1996. New evidence for late mesozoic-early cenozoic evolution of the Chilean Andes in the upper Tinguiririca Valley (35'S), Central Chile. J. S. Am. Earth Sci. 9, 393e422.

Charrier, R., Baeza, O., Elgueta, S., Flynn, J.J., Gans, P., Kay, S.M., Muñoz, N., Wyss, A. R., Zurita, E., 2002. Evidence for Cenozoic extensional basin development and tectonic inversion south of the flat-slab segment, southern Central Andes, Chile (33$36^{\circ}$ S). J. South Am. Earth Sci. Flat-Slab Subduction Andes 15 (1), 117-139.

Comte, D., Farías, M., Charrier, R., Gonzalez, A., 2008. Active tectonics in the Central Chilean Andes: 3D tomography based on the aftershock sequence of the 28 August
2004 shallow crustal earthquake. 7th International Symposium on Andean Geodynamics (ISAG 2008, Nice), pp. 160-163. Extended Abstracts.

Curewitz, D., Karson, J.A., 1997. Structural settings of hydrothermal outflow: fracture permeability maintained by fault propagation and interaction. J. Volcanol. Geoth. Res. 79, 149-168. http://doi:10.1016/S0377-0273(97)00027-9.

Davidson, J., Vicente, J.C., 1973. Características paleogeográficas y estructurales del área fronteriza de las Nacientes del Teno (Chile) y Santa Elena (Argentina) (Cordillera Principal, $35^{\circ}$ a $35^{\circ} 15^{\prime}$ de latitud sur). Actas V Congreso Geológico Argentino Tomo V, pp. 11-55.

Delvaux, D., 1993. The TENSOR Program for Palaeostress Reconstruction: Examples from the East African and the Baikal Rift Zones. Terra Abstract, Abstract (Supplement No.1, to Terra Nova). 5 pp. 216.

Delvaux, D., Sperner, B., 2003. Stress tensor inversion from fault kinematic indicators and focal mechanism data: the TENSOR program. In: Nieuwland, D. (Ed.), New Insights into Structural Interpretation and Modelling: Geol., vol. 212 Soc. Lond. Spec. Publ., pp. 75-100

Dixon, L.F.J., Barker, R., Bray, M., Farres, P., Hooke, J., Inkpen, R., Merel, A., Payne, D., Shelford, A., 1998. Analytical photogrammetry for geomorphological research. In: Lane, S.N., Richards, K.S., Chandler, J.H. (Eds.), Landform Monitoring and Analysis. Wiley, Chichester, pp. 63-94.

Doblas, M., 1998. Slickenside kinematic indicators. Tectonophysics 295 (1), 187-197. https://doi.org/10.1016/S0040-1951(98)00120-6.

Duran, V., Winocur, D., Stern, C., Garvey, R., Barberena, R., Peña Monne, J.L., Benitez, A., 2016. Impacto del volcanismo y glaciarismo holocénicos en el poblamiento humano de la cordillera sur de Mendoza (Argentina): Una perspectiva geoarqueológica. Intersecc. Antropol. 4, 36-46. ISSN 1666-2105. especial 4.

Farías, M., 2007. Tectonique, erosion et evolution du relief dans les Andes du Chili Central au cours du Neogene (Ph.D. thesis). Universite Toulouse III - Paul Sabatier UFR Sciences de la Vie et la Terre.

Farías, M., Comte, D., Charrier, R., Martinod, J., David, C., Tassara, A., Tapia, F., Fock, A., 2010. Crustal-scale structural architecture in central Chile based on seismicity and surface geology: implications for Andean mountain building. Tectonics 29. https://doi.org/10.1029/2009TC002480.

Farías, M., Comte, D., Roecker, S., Carrizo, D., Pardo, M., 2011. Crustal extensional faulting triggered by the 2010 Chilean earthquake: the Pichilemu seismic sequence. Tectonics 30, 11. https://doi.org/10.1029/2011tc002888.

Ferrill, D.A., Winterle, J., Wittmeyer, G., Sims, D., Colton, S., Armstrong, A., Morris, A.P., 1999. Stressed rock strains groundwater at Yucca Mountain, Nevada. GSA Today (Geol. Soc. Am.) 9 (5), 1-8.

Fridriksson, T., Kristjánsson, B.R., Ármannsson, H., Margrétardóttir, E., Ólafsdóttir, S., Chiodini, G., 2006. CO2 emissions and heat flow through soil, fumaroles, and steam heated mud pools at the Reykjanes geothermal area, SW Iceland. Appl. Geochem. 21, 1551-1569. https://doi.org/10.1016/j.apgeochem.2006.04.006.

Giambiagi, L., Ghiglione, M., Cristallini, E., Bottesi, G., 2009. Kinematic models of basement/cover interaction: insights from the Malargüe fold and thrust belt, Mendoza, Argentina. J. Struct. Geol. 31, 1443-1457.

Giambiagi, L., Alavarez, P., Spagnotto, S., Godoy, E., Lossada, A., Mescua, J., Barrionuevo, M., Suriano, J., 2019. Geomechanical model for a seismically active geothermal field: insights from the Tinguiririca volcanic-hydrothermal system. Geoscience Frontiers 10 (6), 2117-2133. https://doi.org/10.1016/j. gsf.2019.02.006. 
Giordano, G., Pinton, A., Cianfarra, P., Baez, W., Chiodi, A., Viramonte, J., Norini, G., Groppelli, G., 2013. Structural control on geothermal circulation in the cerro TuzgleTocomar geothermal volcanic area (Puna plateau, Argentina). J. Volcanol. Geoth. Res. 249, 77-94.

Godoy, E., Yañez, G., Vera, E., 1999. Inversion of an Oligocene volcano-tectonic basin and uplifting of its superimposed Miocene magmatic arc in the Chilean Central Andes: first seismic and gravity evidences. Tectonophysics 306, 217-236.

González-Contreras, A., 2008. Análisis Estructural Entre Los Valles Del Río Tinguiririca Y Teno, Cordillera Principal De Chile Central: Microsismicidad Y Geología Superficial. Tesis de grado. Universidad de Chile (inédita), Santiago, p. 90.

Guzmán, C., Cristallini, E., Bottesi, G., 2007. Contemporary stress orientations in the Andean retroarc between $34^{\circ} \mathrm{S}$ and $39^{\circ} \mathrm{S}$ from borehole breakout analysis. Tectonics 26, TC3016. https://doi.org/10.1029/2006TC001958.

Haller, M., Risso, C., 2011. La erupción del volcán Peteroa ( $\left.35^{\circ} 15^{\prime} \mathrm{S}, 70^{\circ} 18^{\prime} \mathrm{O}\right)$ del 4 de septiembre de 2010. Rev. Asoc. Geol. Argent. 68, 295-305.

Haller, M., Ostera, H., Pesce, A., Gardini, M., Folguera, A., 1994. Vulcanoestratigrafía reciente y eruptividad del Volcán Peteroa. In: Congreso Geológico Chileno, vol. 7. Actas, pp. 319-323 (Concepción).

Hancock, P.L., 1985. Brittle microtectonics: principles and practice. J. Struct. Goel. 7, 437-457.

Healy, D., Rizzo, R.E., Cornwell, D.G., Farrell, N.J., Watkins, H., Timms, N.E., GomezRivas, E., Smith, M.FracPaQ., 2017. A MATLABTM toolbox for the quantification of fracture patterns. J. Struct. Geol. 95, 1-16.

Hevia-Cruz, A., 2014. Evolución Tectono-Estratigráfica De Depósitos Cenozoicos En La Cuenca Del Río Teno, Vertiente Occidental De La Cordillera Principal. Tesis de grado. Universidad de Chile (inédita), Santiago, p. 71.

Hildred, W., Moorbath, S., 1988. Crustal contribution to arc magmatism in the Andes of central Chile. Contrib. Mineral. Petrol. 98, 455-489.

Hill, D.P., 1977. A model for earthquake swarms. J. Geophys. Res. 82 (8), 1247-1352.

Hobbs, B., Means, W., Williams, P., 1976. An Outline of Structural Geology. John Wiley and Sons, Inc., New York, p. 571.

Hutchison, W., Mather, T.A., Pyle, D.M., Biggs, J., Yirgu, G., 2015. Structural controls on fluid pathways in an active rift system: a case study of the Aluto volcanic complex. Geosphere (3), 1-21. https://doi.org/10.1130/GES01119.1.

Jaeger, J.C., Cook, N.G., 1979. Fundamentals of Rock Mechanics, third ed. Chapman and Hall, New York, p. 593. Chapman and Hall.

Kozlowski, E., Manceda, R., Ramos, V.A., 1993. Estructura. In: Ramos, V.A. (Ed.), Geología y Recursos Naturales de Mendoza: 12 Congreso Geológico Argentino y 2 Congreso de Exploración de Hidrocarburos, pp. 235-256. Relatorio.

Lisle, R., Srivastava, D., 2004. Test of the frictional reactivation theory for faults and validity of fault-slip analysis. Geology 32 (7), 569-572.

Manceda, R., Figueroa, D., 1995. Inversion of the mesozoic Neuquén rift in the Malargüe fold thrust belt, Mendoza, Argentina. In: Tankard, A.J. (Ed.), Petroleum Basins of South America: American Association of Petroleum Geologists Memoir, vol. 62, pp. 369-382.

Marrett, R., Allmendinger, R.W., 1990. Kinematic analysis of fault-slip data. J. Struct. Geol. 12 (8), 973-986.

Marten, S.J., Boger, W.A., 1998. Geometry and mechanics of secondary fracturing around small three-dimensional faults in granitic rocks. J. Geophys. Res. 103, $21299 \mathrm{e} 21314$.

Mescua, J.F., Giambiagi, L.B., Ramos, V.A., 2013. Late Cretaceous Uplift in the Malargüe fold-and-thrust belt $\left(35^{\circ} \mathrm{S}\right)$, southern central Andes of Argentina and Chile. Andean Geol. 40 (1), 102-116. https://doi.org/10.5027/andgeoV40n1-a05.

Métois, M., Socquet, A., Vigny, C., 2012. Interseismic coupling, segmentation andmechanical behavior of the central Chile subduction zone. J. Geophys. Res. Solid Earth 117.

Morris, A., Ferrill, D.A., Henderson, D.B., 1996. Slip-tendency analysis and fault reactivation. Geology 24 (3), 275-278.

Mosolf, J., Gans, P.B., Wyss, A.R., Cottle, J.M., Flynn, J.J., 2019. Late Cretaceous to Miocene volcanism, sedimentation and upper-crustal faulting and folding in the Principal Cordillera, central Chile: field and geochronological evidence for protracted arc volcanism and transpressive deformation. Geological Society of America Bulletin. https://doi.org/10.1130/B31998.1.

Naranjo, J., Haller, M., 2002. Erupciones principalmente explosivas del volcán Planchón, Andes del sur (35¹5'S). Rev. Geol. Chile 29, 93-113.

Naranjo, J., Haller, M., Ostera, H., Pesce, A., Sruoga, P., 1999. Geología y Peligros del Complejo Volcánico Planchon-Peteroa, Andes del Sur ( $35^{\circ} 15^{\prime}$ S), Región del Maule, Chile-Provincia de Mendoza, Argentina. 52. Serv. Nac. Geol. Min.

Nullo, F.E., Stephens, G.C., Otamendi, J., Baldauf, P.E., 2002. El volcanismo del Terciario superior del sur de Mendoza. Rev. Asoc. Geol. Argent. 57 (2), 119-132.

Parada, R., 2008. Analisis estructural del borde oriental de la cuenca terciaria de Abanico en el valle del Río Teno, 7ma región. Tesis degrado (inédito). Facultad de Ciencias Físicas y Matematicas. Universidad de Chile.
Pavez, C., Tapia, F., Comte, D., Gutierrez, F., Lira, E., Charrier, R., Benavente, O., 2016. Characterization of the hydrothermal system of the Tinguiririca Volcanic Complex, Central Chile, using structural geology and passive seismic tomography. J. Volcanol. Geoth. Res. 310, 107-117.

Petit, J.P., 1987. Criteria for the sense of movement on fault surfaces in brittle rocks. J. Struct. Geol. 9, 597-608.

Piquer, J., Castelli, J.C., Charrier, R y, Yañez, G., 2010. El Cenozoico del alto río Teno, Cordillera principal, Chile Central: estratigrafía, plutonismo y su relacion con estructuras profundas. Andean Geol. 37 (1), 32-53.

Piquer, J., Yáñez, G., Rivera, O., Cooke, D., 2019. Long-lived crustal damage zones associated with fault intersections in the high Andes of Central Chile. Andean Geol. 46 (2), 223-239. https://doi.org/10.5027/andgeoV46n2-3106.

Pritchard, M.E., Jay, J.A., Aron, F., Henderson, S.T., Lara, L.E., 2013. Subsidence at southern Andes volcanoes induced by the 2010 Maule, Chile earthquake. Nat. Geosci. 6, 632-636. https://doi.org/10.1038/NGEO1855.

Rowland, J.V., Sibson, R.H., 2004. Structural controls on hydrothermal flow in a segmented rift system, Taupo Volcanic Zone, New Zealand. Geofluids 4, 259-283. https://doi.org/10.1111/j.1468-8123.2004.00091.x.

Sibson, H., 1996. Structural permeability of fluid-driven fault-fracture. J. Struct. Geol. 18, 1031-1042.

Sibson, R.H., Rowland, J.V., 2003. Stress, fluid pressure and structural permeability in seismogenic crust, North Island, New Zealand. Geophys. J. Int. 154, 584-594.

Sielfeld, G., Ruz, J., Brogi, A., Cembrano, J., Stanton-Yonge, A., Perez-Flores, P., Iturrieta, P., 2019. Oblique-slip tectonics in an active volcanic chain: a case study from the Southern Andes. Tectonophysics 770. https://doi.org/10.1016/j. tecto.2019.228221.

Siler, D., Faulds, J., Mayhew, B., McNamara, D., 2016. Analysis of the favorability for geothermal fluid flow in 3D: astor Pass geothermal prospect, Great Basin, northwestern Nevada, USA. Geothermics 60, 1-12.

Spagnotto, S.L., Triep, E.G., Giambiagi, L.B., Nacif, S.V., Alvarez, O., 2015. New evidences of rupture of crust and mantle in the subducted Nazca plate and intermediate-depth. J S Am Earth Sci. ISSN 141-147. https://doi.org/10.1016/j. jsames.2014.12.002, 0895-9811 58.

Sperner, B., Müller, B., Heidbach, O., Delvaux, D., Reinecker, J., Fuchs, K., 2003. Tectonic stress in the Earth's crust: advances in the World Stress Map project. In: NIEUWLAND, D.A. (Ed.), New Insights in Structural Interpretation and Modelling Geological Society of London, Special Publication, pp. 101-116.

Stern, C., Futa, K., Muehelnbachs, K., Dobbs, F., Muñoz, J., Godoy, E., Charrier, R., 1984. $\mathrm{Sr}, \mathrm{Nd}, \mathrm{Pb}$ and $\mathrm{O}$ isotope composition of Late Cenozoicvolcanics, northernmost SVZ (33- 34 S). In: Harmon, R., Barriero, B. (Eds.), Andean Magmatism: Chemical and Isotopic Constraints. Shiva Publishing Cheshire, pp. 96-105.

Tapia, F., Farías, M., Naipauer, J., 2015. Late Cenozoic contractional evolution of the current arc-volcanic region along the southern Central Andes ( $35^{\circ} 20^{\prime}$ S). J. Geodyn. 88, 36-51.

Tassi, F., Aguilera, F., Benavente, O., Paonita, A., Chiodini, G., Caliro, S., Agusto, M., Gutierrez, F., Capaccioni, B., Vaselli, O., Caselli, A., Saltori, O., 2016. Geochemistry of fluid discharges from Peteroa volcano (Argentina-Chile) in 2010-2015: insights into compositional changes related to the fluid source region(s). Chem. Geol. 432, 41-53. https://doi.org/10.1016/j.chemgeo.2016.04.007.

Tormey, D., 1989. Geology and Chemistry of the Active Azufre-Planchón-Peteroa Volcanic complex $35^{\circ} 15^{\prime} \mathrm{S}$, Southern Andes: Implications for cordilleran Arc magmatism. Tesis para optar al grado de Doctor (inédita). Instituto Tecnológico de Massachusetts, Massachusetts, Estados Unidos, p. 331.

Tormey, D., Frey, F., López, L., 1995. Geochemistry of the active azufre-planchónpeteroa volcanic complex, Chile $\left(35^{\circ} 15^{\prime} \mathrm{S}\right)$ : evidence for multiple sources and processes in a Cordilleran arc magmatic system. J. Petrol. 36, 265-298.

Vergani, G.D., Tankard, A.J., Belotti, H.J., Welsink, H.J., 1995. Tectonic evolution and paleogeography of the Neuquen basin, Argentina. Memoir. In: Tankard, A.J., Suarez, R.Y., Welsink, H.J. (Eds.), Petroleum Basins of South America, American Association of Petroleum Geologists, vol. 62, pp. 383-402 (Tulsa).

Villegas, A., Raquel, J., Zahradnik, J., Nacif, S., Spagnotto, S., Winocur, D., Flavia Leiva, M., 2016. Waveform inversion and focal mechanisms of two weak earthquakes in Cordillera Principal (Argentina) between 35 degrees and 35.5 degrees S. J. S. Am. Earth Sci. 71, 359-369.

Wise, D.U., Funiciello, R., Parotto, M., Salvini, F., 1985. Topographic lineament swarms: clues to their origin from domain analysis of Italy. Geol. Soc. Am. Bull. 96, 952-967.

Zhang, Y., Schaubs, P.M., Zhao, C., Ord, A., Hobbs, B.E., Barnicoat, A.C., 2008. Fault related dilation, permeability enhancement, fluid flow and mineral precipitation patterns: numerical models. Geol. Soc. Lond. Spec. Publ. 299, 239-255. https://doi. org/10.1144/SP299.15.

Zoback, M.D., Townend, J., 2001. Implications of hydrostatic pore pressures and high crustal strength for the deformation of intraplate lithosphere. Tectonophysics 336, 19-30. 